Check for updates

Cite this: J. Mater. Chem. A, 2020, 8 , 19454

Received 23rd May 2020

Accepted 2nd September 2020

DOI: $10.1039 / \mathrm{dOta0} 5255 \mathrm{~h}$

rsc.li/materials-a

\section{Synthesis and in situ ion irradiation of A-site deficient zirconate perovskite ceramics $\uparrow$}

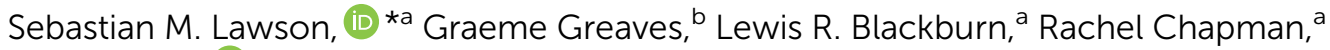
Neil C. Hyatt $\mathbb{D}^{a}$ and Claire L. Corkhill ${ }^{a}$

The influence of $A$-site vacancies on zirconate perovskite structured ceramics of formula $\mathrm{A}_{1-x} \mathrm{La}_{2 \times / 3} \mathrm{ZrO}_{3}(\mathrm{~A}$ $=\mathrm{Ca}, \mathrm{Sr}, \mathrm{Ba}$ ) has been investigated using $400 \mathrm{keV} \mathrm{Kr}{ }^{+}$in situ ion irradiation in a TEM with varied temperature from $100 \mathrm{~K}$ to $673 \mathrm{~K}$. The solubility limit of La within the $\mathrm{Ba}_{1-x} \mathrm{La}_{2 x / 3} \mathrm{ZrO}_{3}$ system was $5.33 \mathrm{ml} \%(x=0.08)$ using a solid-state synthesis route, with space group symmetry of $P m \overline{3} m$ for $x \leq 0.08$. The $\mathrm{Ca}_{0.9} \mathrm{La}_{0.067} \mathrm{ZrO}_{3}$ and $\mathrm{Sr}_{0.9} \mathrm{La}_{0.067} \mathrm{ZrO}_{3}$ samples were found to synthesise single-phase with the Pcmn and Pbnm symmetries of their respective end member structures. The addition of $6.67 \mathrm{ml} \% \mathrm{La}(x=0.1)$ in $\mathrm{CaZrO}_{3}$ and $\mathrm{SrZrO}_{3}$ was found to decrease the critical temperature of amorphisation, $T_{\mathrm{c}}$, in comparison with the undoped structures. A similar decrease was found for the $5.33 \mathrm{ml} \% \mathrm{La}$ doped $\mathrm{BaZrO}_{3}$ structure. Namely, values were observed for doped samples of $\approx 404 \mathrm{~K}, \approx 520 \mathrm{~K}$ and $\approx 621 \mathrm{~K}(\mathrm{~A}=\mathrm{Sr}, \mathrm{Ca}, \mathrm{Ba}$ respectively), compared to $\approx 440 \mathrm{~K}, \approx 623 \mathrm{~K}$ and $\approx 675 \mathrm{~K}$ for $\mathrm{SrZrO}_{3}, \mathrm{CaZrO}_{3}$ and $\mathrm{BaZrO}_{3}$, respectively. This follows similar behaviour to that observed in titanate systems at low dopant levels, and these findings have been discussed in relation to both the presence of cation vacancies in the doped samples and the presence of the La cation. Void formation, growth and induced morphology changes have also been characterised, onset by ion irradiation.
\end{abstract}

\section{Introduction}

Perovskite structured materials have been widely investigated for various material applications, including as fuel cells, ${ }^{1-4}$ dielectric resonators, ${ }^{5-7}$ photovoltaics, ${ }^{8,9}$ light emitting diodes, ${ }^{10}$ lasers, ${ }^{11,12}$ next generation nuclear fuels ${ }^{13,14}$ and as hightemperature superconducting magnets. ${ }^{15-18}$ Another potential application is in the immobilisation of nuclear waste streams as a host ceramic matrix. The namesake perovskite $\mathrm{CaTiO}_{3}$ has been widely studied as a direct immobilisation matrix, including as a constituent of the SYNROC study, ${ }^{19-24}$ while it is a commonly observed secondary actinide bearing phase when targeting zirconolite structured systems. ${ }^{25-30}$

In the context of nuclear waste disposal, waste immobilisation matrices will be required to operate with a service lifetime on geological timescales $\left(\approx 10^{6}\right.$ years $)$ due to the long half-lives of the isotopes in question. Over such timescales, doping a ceramic structure like perovskite with actinides, i.e. $\mathrm{U}, \mathrm{Pu}, \mathrm{Am}$, will impart significant radiation damage to the crystalline matrix from alpha-decay processes. Key to ceramic performance in this context will be the damage required to amorphise the

${ }^{a}$ Immobilisation Science Laboratory, Department of Materials Science and Engineering, University of Sheffield, UK

${ }^{b}$ School of Computing and Engineering, University of Huddersfield, UK

$\dagger$ Electronic supplementary information (ESI) available: Bright-field TEM and EELS spectra for grains of doped perovskite samples. See DOI: $10.1039 /$ dota05255h crystalline structure, a consequence of which could be increased leaching rates in contact with ground water should a disposal canister fail. In this context, previous studies of radiation damage in perovskites have focused on the titanate series, ${ }^{31-47}$ while niobates and tantalates have also received attention. ${ }^{48}$ Zirconate systems, namely $\mathrm{CaZrO}_{3}, \mathrm{SrZrO}_{3}$ and $\mathrm{BaZrO}_{3}$, have received little attention, although the response of $\mathrm{CaZrO}_{3}$ to swift heavy ions has been previously investigated. ${ }^{49}$ The focus of the present study, therefore, is investigation of radiation damage effects within these zirconate systems using in situ ion irradiation techniques. Such techniques are frequently employed to calculate amorphisation doses over accelerated timescales.

Perovskite structured materials take the base structural formula $\mathrm{ABO}_{3}$ and an array of elemental combinations have been synthesised and characterised. The aristotype perovskite structure is exhibited by $\mathrm{SrTiO}_{3}$ in a cubic $P m \overline{3} m$ arrangement, with $\mathrm{Sr}$ cations located at the unit cell corners, a body centred Ti cation and face-centred corner sharing $\mathrm{O}$ atoms, forming corner sharing $\mathrm{TiO}_{6}$ octahedra throughout the structure. While $\mathrm{SrTiO}_{3}$ exhibits the ideal ratio of $\mathrm{A} / \mathrm{B}$ site cation radii (as governed by the Goldschmidt tolerance factor ${ }^{50}$ ), distorted structures can form when this ratio changes through the tilting of $\mathrm{BO}_{6}$ octahedra and, for example, anti-parallel A-site cation displacement. Within this study, the $\mathrm{CaZrO}_{3}, \mathrm{SrZrO}_{3}$ and $\mathrm{BaZrO}_{3}$ compositions have been investigated, and these structures are shown graphically in Fig. 1. $\mathrm{CaZrO}_{3}$ presents at room temperature in the 
(a) $\mathrm{CaZrO}_{3}$

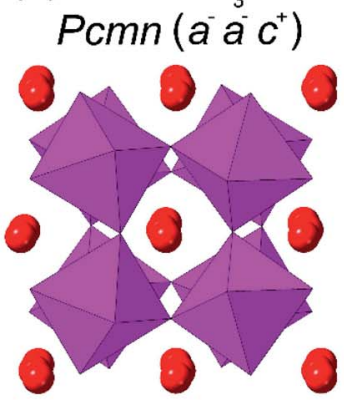

(b) $\mathrm{SrZrO}_{3}$

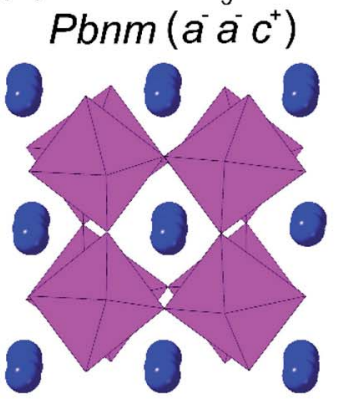

(c) $\mathrm{BaZrO}_{3}$
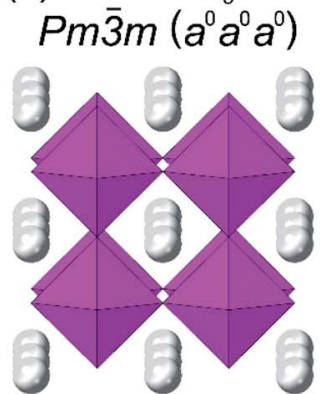

Fig. 1 Structures of (a) $\mathrm{CaZrO}_{3}\left(P c m n ; a^{-} a^{-} c^{+}\right)$, (b) $\mathrm{SrZrO}_{3}\left(P b n m ; a^{-} a^{-} c^{+}\right)$and (c) $\mathrm{BaZrO}_{3}\left(P m 3 m ; a^{0} a^{0} a^{0}\right)$, as viewed slightly tilted off the [100] cubic direction. $\mathrm{Ca}$ ions are presented as red spheres, $\mathrm{Sr}$ ions as blue spheres, Ba ions as white spheres and $\mathrm{ZrO}_{6}$ octahedra in pink. Figures were produced using the CrystalMaker software package using structural information from Levin et al. ${ }^{7}$ Kennedy et al. ${ }^{54}$ and Parida et al. ${ }^{59}$

orthorhombic Pcmn $\left(a^{-} a^{-} c^{+}\right.$using Glazer notation $\left.{ }^{51}\right)$, with $\mathrm{CaZrO}_{3}$ reported to remain orthorhombic $<2023 \mathrm{~K}$ prior to a transition to cubic symmetry. ${ }^{52,53} \mathrm{SrZrO}_{3}$ takes the Pbnm $\left(a^{-} a^{-} c^{+}\right)$structure, with temperature induced phase transitions investigated by various groups. ${ }^{54-56}$ Most recently Hasegawa et $a .^{57}$ revisited the $\mathrm{SrZrO}_{3}$ system and reported transitions to Ibmm $\left(a^{-} a^{-} c^{0}\right)$ at $1042 \mathrm{~K}, I 4 / m c m\left(a^{0} a^{0} c^{-}\right)$at $1119 \mathrm{~K}$ and to $P m \overline{3} m$ $\left(a^{0} a^{0} a^{0}\right)$ at $1375 \mathrm{~K} . \mathrm{BaZrO}_{3}$ has the aristotype perovskite structure of $P m \overline{3} m\left(a^{0} a^{0} a^{0}\right)$, with no temperature related phase-transitions reported within the literature from $10 \mathrm{~K}$ to $1273 \mathrm{~K} \cdot{ }^{58-60}$ Both space groups Pcmn and Pbnm are non-stand settings of Pnma (space group 62), however, within this work we refer to the most commonly used settings within the literature.

A further consequence of doping the perovskite $\mathrm{ABO}_{3}$ structure is the likely induction of cation vacancy defects. Perovskite structures have been reported to exhibit a remarkable tolerance for such cation deficiency, and this has been hypothesised in a disposal context through doping experiments with La and $\mathrm{Gd} .^{61}$ When considering the multivalent nature of those isotopes suitable for ceramic immobilisation, understanding the effects of cation deficiency on radiation effects is of key interest. Titanate compositions investigated in this regard include the A-site deficient $\mathrm{Sr}_{1-x} \mathrm{La}_{2 x / 3} \mathrm{TiO}_{3}$ (ref. 62) and $\mathrm{Ca}_{1-x^{-}}$ $\mathrm{La}_{2 x / 3} \mathrm{TiO}_{3}$ (ref. 63 and 64) systems. A-site cation vacancies are produced within these systems whereby a cation vacancy is induced for every two dopant La cations. In both of these systems, in situ ion irradiation in a transmission electron microscope (TEM) has shown a reduction in the critical temperature of amorphisation, $T_{\mathrm{c}}$, in the $0.1 \leq x \leq 0.4$ region. This value is defined as the temperature at which the damage rate equals the rate of recovery from damage, for a specific irradiation condition. A lower $T_{\mathrm{c}}$ value can therefore be interpreted as a sample having recovery characteristics that require less thermal energy to suppress amorphisation under irradiation. While this could be linked to a possible higher displacement energy for La, for $\geq 0.5 T_{\mathrm{c}}$ was found to increase with respect to each end member, producing the opposite trend at higher La contents. It has been hypothesised that the increased A-site vacancy content in these systems increases recovery rates through increased defect migration and the increased likelihood for recombination events on the perovskite A-site.
Therefore, as well as studying the end-member zirconate systems, this paper presents work to investigate whether such effects translate to zirconate perovskite systems in the context of nuclear waste disposal. To this purpose, samples of $\mathrm{Ca}_{0.9^{-}}$ $\mathrm{La}_{0.067} \mathrm{ZrO}_{3}, \mathrm{Sr}_{0.9} \mathrm{La}_{0.067} \mathrm{ZrO}_{3}$ and $\mathrm{Ba}_{0.92} \mathrm{La}_{0.053} \mathrm{ZrO}_{3}$ were also synthesised and investigated using in situ ion irradiation. Synthesis and irradiation of a $\mathrm{Ba}_{0.9} \mathrm{La}_{0.067} \mathrm{ZrO}_{3}$ sample was intended, however, a study to find the solubility limit of La within $\mathrm{BaZrO}_{3}$ determined this sample would not synthesise, as is presented within this paper.

\section{Experimental}

\subsection{Sample synthesis}

Compositions of $\mathrm{A}_{1-x} \mathrm{La}_{2 x / 3} \mathrm{ZrO}_{3}(\mathrm{~A}=\mathrm{Ca}, \mathrm{Sr} ; x=0$ and 0.1$)$ and $\mathrm{Ba}_{1-x} \mathrm{La}_{2 x / 3} \mathrm{ZrO}_{3}(x=0,0.02,0.04,0.06,0.08$ and 0.1$)$ were synthesised via a solid-state route. The additional $\mathrm{Ba}_{1-x} \mathrm{La}_{2 x /}$ ${ }_{3} \mathrm{ZrO}_{3}$ samples were synthesised in order to find the solubility limit of $\mathrm{La}$ in this system. Stoichiometric quantities of $\mathrm{CaCO}_{3}$, $\mathrm{SrCO}_{3}, \mathrm{BaCO}_{3}, \mathrm{ZrO}_{2}$ (all 99.9\%; Sigma-Aldrich), each dried at $180{ }^{\circ} \mathrm{C}$, and $\mathrm{La}_{2} \mathrm{O}_{3}$ (99.9\%; Sigma-Aldrich), dried at $800{ }^{\circ} \mathrm{C}$, were weighed to stoichiometric amounts and milled in isopropanol using a planetary ball mill with silicon nitride milling media for 15 minutes at $400 \mathrm{rpm}$. After milling to homogeneity, powders were dried at $80^{\circ} \mathrm{C}$, sieved $(212 \mu \mathrm{m}$; steel $)$ and uniaxially pressed into $10 \mathrm{~mm}$ pellets to produce green bodies. Samples were then fired in zirconia crucibles at $1450{ }^{\circ} \mathrm{C}$ for 48 hours in air, reground using an agate pestle and mortar and re-sieved to produce fine, reacted powders.

\section{$2.2 \mathrm{X}$-ray diffraction}

X-ray diffraction (XRD) was undertaken using a Panalytical $\mathrm{X}^{\prime}$ pert ${ }^{3}$ powder diffractometer, operating at $45 \mathrm{mV}, 40 \mathrm{~mA}$ with $\mathrm{Cu} \mathrm{K} \alpha(\lambda=1.5418 \AA)$. The scan range was $10^{\circ}$ to $90^{\circ}$ with a step size of $0.02^{\circ}$ and step time of $0.2 \mathrm{~s}$. A $1 / 4^{\circ}$ divergent slit was employed with 0.02 rad Soller slits. Powders were backloaded into sample holders with the rear surface of packed powders exposed to the X-ray beam, minimising preferential orientation. All data were calibrated using an external NIST 640e line position standard (ESI Fig. 1†). Lattice parameter refinement was 
undertaken using the Bruker TOPAS software package, with all errors reported as calculated by the refinement process. Such errors were likely underestimated due to the use of a laboratorybased X-ray source and this should be noted when referring to the lattice parameters.

\subsection{Transmission Electron microscopy}

TEM analysis was undertaken using a JEOL F200, operating at $200 \mathrm{keV}$, with images and electron diffraction patterns captured using a Gatan OneView. Electron energy loss spectroscopy (EELS) was undertaken using a Gatan Image Filter (GIF) Quantum SE. Samples were prepared for TEM via the powdered "crushed grain" route, with powder ground in isopropanol and pipetted onto a carbon holey lined Cu TEM grid.

\subsection{In situ ion irradiation}

In situ ion irradiation was undertaken at the University of Huddersfield's MIAMI (Microscopes and Ion Accelerators for Materials Investigations) facility. The MIAMI-2 system was utilised, which comprises a Danfysik 921A ion source coupled with a $350 \mathrm{kV}$ National Electrostatics Corporation ion accelerator, with the ion beam entering the TEM column of a $300 \mathrm{kV}$ Hitachi $\mathrm{H}-9500 \mathrm{TEM}$ at an angle of $18.7^{\circ}$ to the electron beam. ${ }^{65}$ Samples were prepared via the crushed grain route as described previously, with Au grids used for temperatures of $>300 \mathrm{~K}$ and $\mathrm{Cu}$ for $\leq 300 \mathrm{~K}$. Prior to ion irradiation, the presence of each intended element in the target composition of the specific grains monitored was confirmed via EELS spectroscopy using a Gatan Image Filter (GIF) Quantum SE.

The ion beam setup employed was $400 \mathrm{keV} \mathrm{Kr}^{+}$ions with a flux of $2 \pm 0.2 \times 10^{12}$ ions per $\mathrm{cm}^{2} . \mathrm{Kr}^{+}$was employed for comparative purposes with the studies of Smith et al. ${ }^{63}$ and Whittle et al. ${ }^{\mathbf{6 4}}$ Nuclear/electron stopping powers and ratios for each composition were estimated using the SRIM Monte Carlo code. ${ }^{66}$ The "Ion Distribution and Quick Calculation of Damage" option was used with an average displacement energy of $50 \mathrm{eV}$ set for each constituent element. Values calculated using SRIM are summarised in Table 1, including the determined theoretical densities of the powders used in the calculations and a ratio of electron to nuclear stopping powers (ENSP). Graphical SRIM curves are presented in ESI Fig. 2. $\dagger$ Under these conditions, stopping mechanisms were dominated by the nuclear component in all cases. Considering a TEM grain thickness of $<100 \mathrm{~nm}$, it was a requirement to induce displacement damage across the entire grain to observe full amorphisation. Peak displacement damage depth was estimated by SRIM to be $90 \pm 10 \mathrm{~nm}$ in all cases, extending to a full damage range of $\approx 200 \mathrm{~nm}$, ensuring the entire grain was subject to displacement damage. For each sample, the $\mathrm{Kr}$ retention to a thickness of $<100 \mathrm{~nm}$ was estimated to be $<5 \%$ by integrating the SRIM profiles for implantation depth.

The electron beam valve was closed while ion irradiation was undertaken in order to avoid dual-beam synergistic effects, with the ion beam blocked off at intervals to allow for imaging and electron diffraction analysis. Several grains were monitored at each interval using bright-field (BF) imaging and selective area electron diffraction (SAED). A Gatan 652 heating holder was used for irradiations at elevated temperatures, and a Gatan 636 liquid nitrogen cooling stage was used for temperatures below ambient. An average of the time/fluence interval at which all Bragg diffraction peaks diminished and only amorphous diffuse scattering was observed within SAED patterns and the previous interval was taken as the critical amorphisation fluence, $F_{\mathrm{c}}$, at a given temperature. This process for a $\mathrm{SrZrO}_{3}$ grain is shown in Fig. 2. The error in $F_{\mathrm{c}}$ was taken as the difference between the two intervals in which $F_{\mathrm{c}}$ was observed to fall. An average of $F_{\mathrm{c}}$ from all monitored grains gave the final $F_{\mathrm{c}}$ value for a particular sample and temperature. An additional 10\% error in the flux was applied to account for fluctuations in the ion beam. The ion beam flux was also measured before and after irradiation to further monitor beam stability.

By measuring $F_{\mathrm{c}}$ as a function of temperature, the critical temperature of amorphisation, $T_{\mathrm{c}}$, was determined. $T_{\mathrm{c}}$ is defined as the temperature at which the rate of damage induced equals the rate of recovery from damage under specific irradiation conditions. As previously implemented by various groups, ${ }^{37,62,63,67-76}$ values of $T_{\mathrm{c}}$ were calculated using a nonlinear least squares refinement of eqn (1) using several models that can be accessed elsewhere. ${ }^{77,78}$

$$
F_{\mathrm{c}}=F_{\mathrm{c} 0} / 1-\exp \left[\left(\frac{E_{\mathrm{a}}}{k_{\mathrm{b}}}\right)\left(\frac{1}{T_{\mathrm{c}}}-\frac{1}{T}\right)\right]
$$

where $F_{\mathrm{co}}$ is the critical amorphisation fluence at $0 \mathrm{~K}, E_{\mathrm{a}}$ is the activation energy for recovery from radiation damage, $k_{\mathrm{b}}$ is the Boltzmann constant $\left(8.6173 \times 10^{-5} \mathrm{eV} \mathrm{K}^{-1}\right)$ and $T$ is temperature. $F_{\mathrm{co}}$ was extrapolated from the acquired data using eqn (1).

Table 1 SRIM parameters and stopping powers ${ }^{a}$

\begin{tabular}{|c|c|c|c|c|}
\hline Sample & Density $\left(\mathrm{g} \mathrm{cm}^{-3}\right)$ & $(\mathrm{d} E / \mathrm{d} x)_{\mathrm{n}}\left(\mathrm{eV} \mathrm{nm}^{-1}\right)$ & $(\mathrm{d} E / \mathrm{d} x)_{\mathrm{e}}\left(\mathrm{eV} \mathrm{nm}^{-1}\right)$ & ENSP \\
\hline $\mathrm{CaZrO}_{3}$ & 4.62 & 1702 & 453.0 & 0.2662 \\
\hline $\mathrm{Ca}_{0.9} \mathrm{La}_{0.067} \mathrm{ZrO}_{3}$ & 4.73 & 1696 & 456.9 & 0.2694 \\
\hline $\mathrm{Sr}_{0.9} \mathrm{La}_{0.067} \mathrm{ZrO}_{3}$ & 5.47 & 1719 & 488.1 & 0.2839 \\
\hline $\mathrm{BaZrO}_{3}$ & 6.23 & 1703 & 514.5 & 0.3021 \\
\hline $\mathrm{Ba}_{0.9} \mathrm{La}_{0.067} \mathrm{ZrO}_{3}$ & 6.16 & 1691 & 510.4 & 0.3018 \\
\hline
\end{tabular}

${ }^{a}$ Density $\left(\mathrm{g} \mathrm{cm}^{-3}\right)$, energy loss to nuclear stopping $(\mathrm{d} E / \mathrm{d} x)_{\mathrm{n}}\left(\mathrm{eV} \mathrm{nm}^{-1}\right)$, energy loss to electronic stopping $(\mathrm{d} E / \mathrm{d} x)_{\mathrm{e}}\left(\mathrm{eV} \mathrm{nm}{ }^{-1}\right)$ and electronic to nuclear stopping power ratio ENSP. 


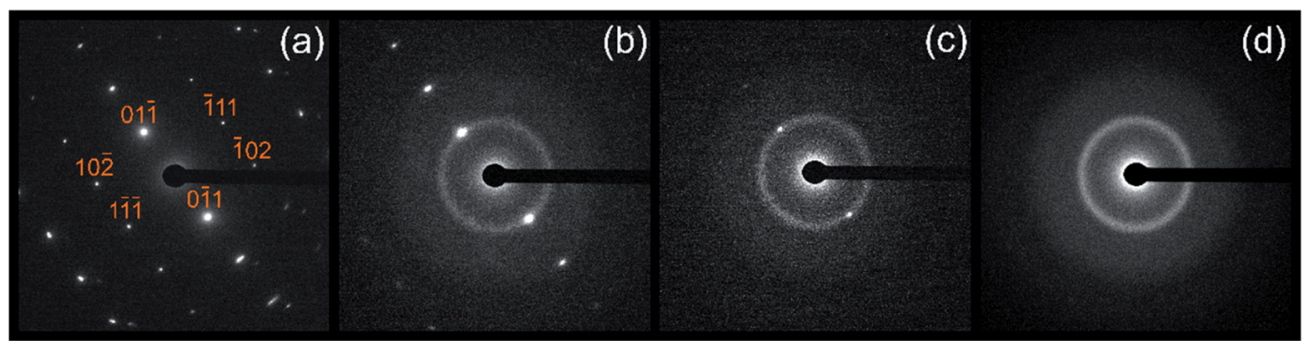

Fig. 2 SAED patterns of a $\mathrm{SrZrO}_{3}$ grain taken at intervals during irradiation to determine the critical fluence for amorphisation, $F_{\mathrm{c}}$, at room temperature. Fluences are (a) $0 F_{c}$ (b) $0.35 F_{c}$, (c) $0.8 F_{c}$, (d) $F_{c}$. (a) is indexed to the [211] direction in Pbnm.

The frequent underestimation of $E_{\mathrm{a}}$ has been reported using eqn (1) when compared to defect migration energies reported in oxides. Therefore, as for other studies, the relationship developed by Weber ${ }^{77}$ was employed to determine both the thermal and irradiation assisted activation energies for recovery from damage, as outlined in eqn (2).

$$
E_{\mathrm{a}}=T_{\mathrm{c}}\left[k_{\mathrm{b}} \ln \left(\frac{F_{\mathrm{c} 0} \nu}{\phi}\right)\right]
$$

where $\phi$ is the ion flux and $\nu$ the effective jump frequency. Values for irradiation-assisted $\left(10^{12} \mathrm{~s}^{-1}\right)$ and thermal $\left(10^{9} \mathrm{~s}^{-1}\right)$ jump frequency were used based on previously reported estimations to allow for calculation of $E_{\text {a }}$ values for both thermal $\left(E_{\text {th }}\right)$ and irradiation assisted $\left(E_{\text {irr }}\right)^{37,62,63,76}$

\section{Results and discussion}

\subsection{Sample synthesis}

Initially, samples of target compositions $\mathrm{CaZrO}_{3}, \mathrm{Ca}_{0.9} \mathrm{La}_{0.067^{-}}$ $\mathrm{ZrO}_{3}, \mathrm{SrZrO}_{3}, \mathrm{Sr}_{0.9} \mathrm{La}_{0.067} \mathrm{ZrO}_{3}, \mathrm{BaZrO}_{3}$ and $\mathrm{Ba}_{0.9} \mathrm{La}_{0.067} \mathrm{ZrO}_{3}$ were synthesised. XRD patterns of the $\mathrm{Ca}_{1-x} \mathrm{La}_{2 x / 3} \mathrm{ZrO}_{3}, \mathrm{Sr}_{1-x} \mathrm{La}_{2 x /}$ ${ }_{3} \mathrm{ZrO}_{3}$ and $\mathrm{Ba}_{1-x} \mathrm{La}_{2 x / 3} \mathrm{ZrO}_{3}(x=0$ and 0.1$)$ samples are presented in Fig. 3a-c, respectively. Magnifications of the highest intensity perovskite reflections are included; (121) in Pcmn, (112) in Pbnm and (110) in the ideal cubic $P m \overline{3} m$. For the $\mathrm{Ca}_{1-x} \mathrm{La}_{2 x / 3} \mathrm{ZrO}_{3}$ and $\mathrm{Sr}_{1-x} \mathrm{La}_{2 x / 3} \mathrm{ZrO}_{3}$ systems, no additional peaks were identified other than those related to their end member counterparts, confirming the parent structure was maintained by the doped samples, i.e. Pcmn for $\mathrm{CaZrO}_{3}$ and $\mathrm{Ca}_{0.9} \mathrm{La}_{0.067} \mathrm{ZrO}_{3} ;$ Pbnm for $\mathrm{SrZrO}_{3}$ and $\mathrm{Sr}_{0.9} \mathrm{La}_{0.067} \mathrm{ZrO}_{3}$. La incorporation into the structures was confirmed through lattice parameter contraction/expansion, as can be observed through the shifts of diffraction peaks to lower $2 \theta$ values (higher $d$-spacing) for $\mathrm{Ca}_{0.9} \mathrm{La}_{0.067} \mathrm{ZrO}_{3}$, and higher $2 \theta$ values (lower $d$-spacing) for $\mathrm{Sr}_{0.9} \mathrm{La}_{0.067} \mathrm{ZrO}_{3}$. These shifts are readily observable in the magnified regions in Fig. $3 \mathrm{a}$ and $b$, and lattice parameters for all samples are reported in Table 2 with fitting errors. The expansion in lattice parameters for $\mathrm{Ca}_{0.9} \mathrm{La}_{0.067} \mathrm{ZrO}_{3}$ was due to the smaller ionic radius of $\mathrm{La}(1.16$ A) when replacing $\mathrm{Ca}(1.12 \AA)$ in 8-fold coordination, while $\mathrm{Sr}_{0.9} \mathrm{La}_{0.067} \mathrm{ZrO}_{3}$ lattice parameters contract due to the larger Sr $(1.26 \AA)$ that is replaced, again in 8-fold coordination.

While lattice contraction was observed in the $\mathrm{Ba}_{0.9} \mathrm{La}_{0.067^{-}}$ $\mathrm{ZrO}_{3}$ sample as compared to $\mathrm{BaZrO}_{3}$, a secondary phase of the pyrochlore-structured $\mathrm{La}_{2} \mathrm{Zr}_{2} \mathrm{O}_{7}$ was detected (see Fig. 3c). This suggested the solubility of La within the $\mathrm{Ba}_{1-x} \mathrm{La}_{2 x / 3} \mathrm{ZrO}_{3}$ system was below $x=0.1$ for this synthesis route. This was likely due to the large difference in size between $\mathrm{Ba}(1.61 \AA)$ and $\mathrm{La}(1.36 \AA)$ in the A-site 12 -fold coordination state in $P m \overline{3} m$. The Goldschmidt tolerance factor, ${ }^{50} t$, has been extensively used to predict the chemical compositions that will form as perovskites, however,
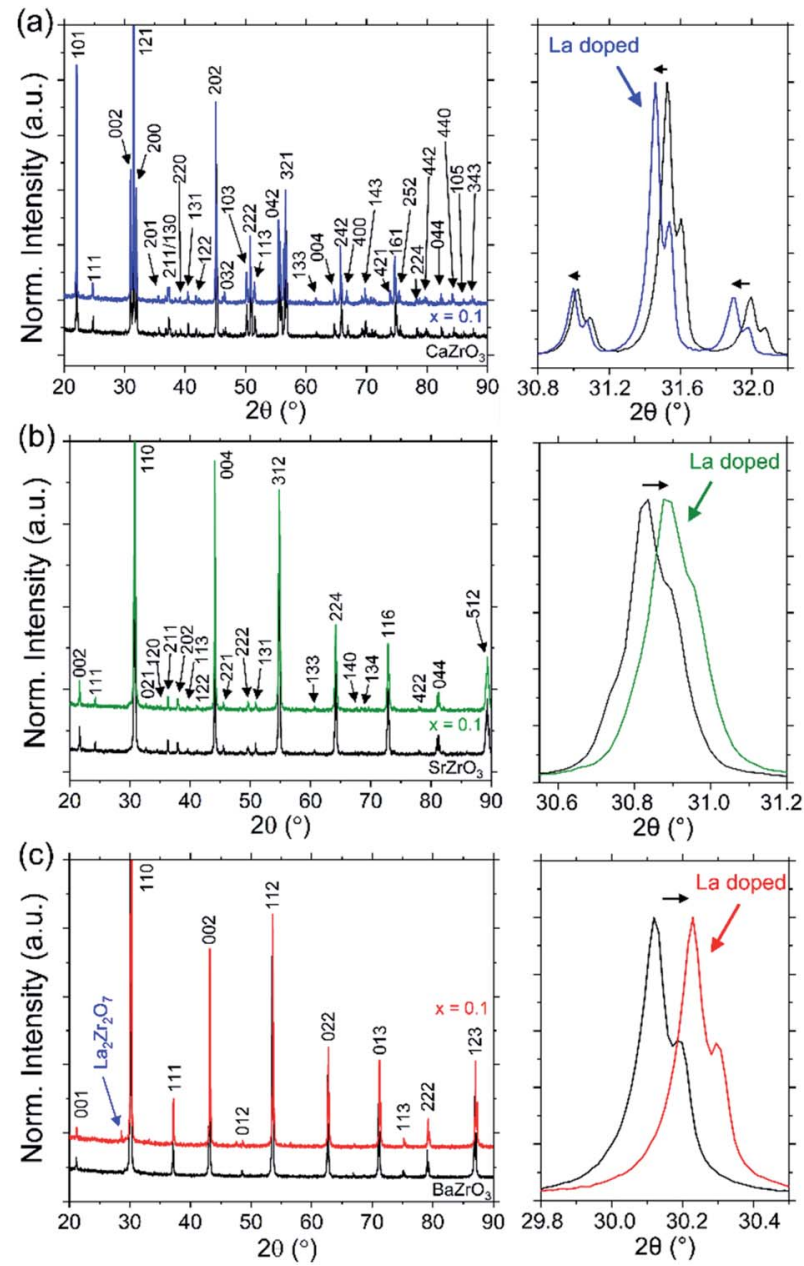

Fig. 3 XRD patterns of as labelled (a) $\mathrm{CaZrO}_{3}$ and $\mathrm{Ca}_{0.9} \mathrm{La}_{0.067} \mathrm{ZrO}_{3}$, (b) $\mathrm{SrZrO}_{3}$ and $\mathrm{Sr}_{0.9} \mathrm{La}_{0.067} \mathrm{ZrO}_{3}$ and (c) $\mathrm{BaZrO}_{3}$ and $\mathrm{Ba}_{0.9} \mathrm{La}_{0.067} \mathrm{ZrO}_{3}$. A magnification of the most intense reflection is presented alongside the full patterns. Patterns are normalised to the most intense reflection. Patterns are indexed to structure information from ICSD database codes $97474\left(\mathrm{CaZrO}_{3}\right), 173398(\mathrm{SrZrO} 3)$ and $90049\left(\mathrm{BaZrO}_{3}\right)$. 


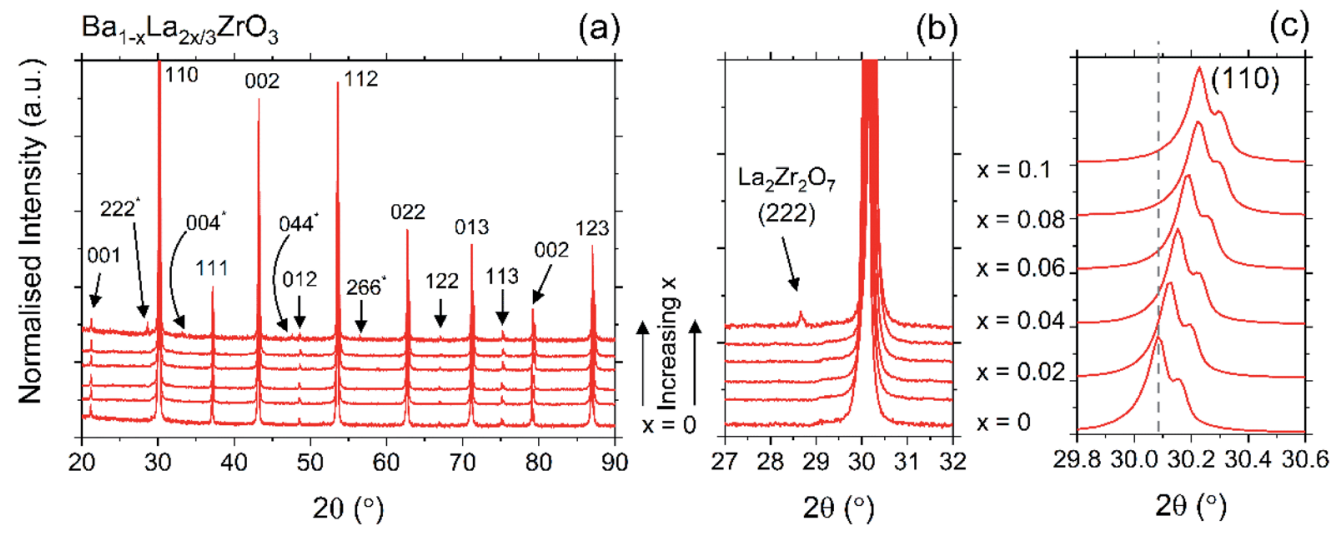

Fig. 4 (a) Full XRD traces of the $\mathrm{Ba}_{1-x} \mathrm{La}_{2 x / 3} \mathrm{ZrO}_{3}$ samples $(x=0,0.02,0.04,0.06,0.08$ and 0.1$)$. Indexing is provided to the $P m 3 m$ structure with reflections indexed to $\mathrm{La}_{2} \mathrm{Zr}_{2} \mathrm{O}_{7}$ indicated with a superscript*. Patterns are indexed based on structural information from ICSD database codes $90049\left(\mathrm{BaZrO}_{3}\right)$ and $153222\left(\mathrm{La}_{2} \mathrm{Zr}_{2} \mathrm{O}_{7}\right)$. The bottom trace is $x=0$ as labelled, with each trace above increasing in increments of $x=0.02$. (b) Magnification of the $27^{\circ} \leq 2 \theta \leq 32^{\circ}$ region indicating the (222) $\mathrm{La}_{2} \mathrm{Zr}_{2} \mathrm{O}_{7}$ reflection present in the $x=0.1$ sample and (c) magnification of the (110) reflection. The grey dashed line indicates the position of the (110) reflection of the $x=0$ sample.

to our knowledge no tolerance factor exists that can accurately predict the effects of A-site vacancies on the likelihood of perovskite formation. Considering an average cation radius based on either a fully occupied La site (i.e. $\mathrm{Ba}_{0.9} \mathrm{La}_{0.1} \mathrm{ZrO}_{3}$ ) or the correct ratio (ignoring the presence of vacancies, as suggested by Ganguly et al. ${ }^{79}$ ) reduces $t$ below the ideal $\mathrm{BaZrO}_{3}$ value of $\approx 1$, but is still in the regime for perovskite formation. As Whittle et al. ${ }^{80}$ report, vacancy defects can occupy more space than a fully-occupied cation lattice site, which is contrary to both these calculations. Without a tolerance factor that truly incorporates a specific vacancy-type defect, such calculations can never be considered accurate. Even so, the incorporation of a quantity of La within the target $\mathrm{Ba}_{0.9} \mathrm{La}_{0.067} \mathrm{ZrO}_{3}$ formula was confirmed by the peak shift observed in Fig. 3c, confirming lattice expansion due to ionic substitution.

Samples of composition $x=0.02,0.04,0.06$ and 0.08 were produced to identify the La solubility limit in $\mathrm{Ba}_{1-x} \mathrm{La}_{2 x / 3} \mathrm{ZrO}_{3}$. XRD patterns of the $\mathrm{Ba}_{1-x} \mathrm{La}_{2 x / 3} \mathrm{ZrO}_{3}$ system for $x=0,0.02,0.04$,
0.06, 0.08 and 0.1 are presented in Fig. 4a, with magnifications of the $27^{\circ} \leq 2 \theta \leq 32^{\circ}$ region in Fig. $4 \mathrm{~b}$ and the (110) reflection in Fig. 4c. A magnification of the $27^{\circ} \leq 2 \theta \leq 32^{\circ}$ region in which the (222) pyrochlore $\mathrm{La}_{2} \mathrm{Zr}_{2} \mathrm{O}_{7}$ reflection was observed is presented in Fig. 4b. For $x \leq 0.08$, no such reflection was observed, confirming the solubility limit of La in the region $0.08 \leq x<0.1$. For $x \leq 0.08$ the $P m \overline{3} m$ structure was present, confirming the single-phase nature of these samples. A shift to higher $2 \theta$ values was observed incrementally with increasing La content (Fig. 4c) until $x=0.1$, with calculated lattice parameters and unit cell volumes reported in Table 2. A linear decrease in unit cell volume was observed for the $\mathrm{Ba}_{1-x} \mathrm{La}_{2 x / 3} \mathrm{ZrO}_{3}$ system until the solubility limit was reached at $x=0.1$. The contraction and expansion of the unit cells of the $\mathrm{Sr}_{1-x} \mathrm{La}_{2 x / 3} \mathrm{ZrO}_{3}$ and $\mathrm{Ca}_{1-x} \mathrm{La}_{2 x /}$ ${ }_{3} \mathrm{ZrO}_{3}$ systems was also observed, as is reported in Table 2.

Bisen et al. ${ }^{81}$ report that the solubility of La within the $\mathrm{Ba}_{1-x} \mathrm{La}_{2 x / 3} \mathrm{ZrO}_{3}(x=0,0.02,0.04,0.06,0.08,0.1)$ solid-solution extends to $x=0.1$. They also report an extreme lattice

Table 2 Calculated lattice parameters of the $\mathrm{Ca}_{1-x} \mathrm{La}_{2 \times / 3} \mathrm{ZrO}_{3}, \mathrm{Sr}_{1-x} \mathrm{La}_{2 \times / 3} \mathrm{ZrO}_{3}$ and $\mathrm{Ba}_{1-x} \mathrm{La}_{2 \times / 3} \mathrm{ZrO}_{3}$ systems ${ }^{a}$

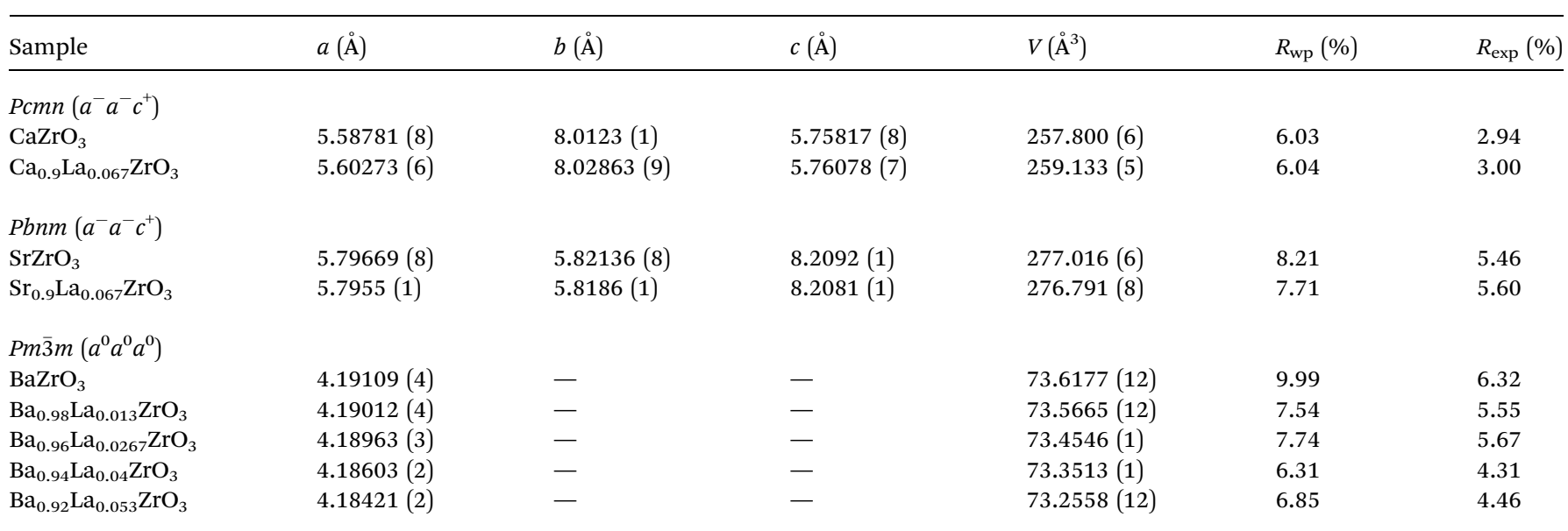

${ }^{a}$ Lattice parameters $a, b$ and $c(\AA)$, unit cell volume $V\left(\AA^{3}\right)$ and refinement errors $R_{\mathrm{wp}}$ and $R_{\exp }(\%)$. 


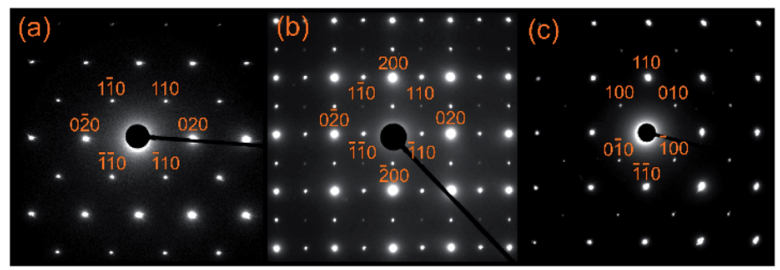

Fig. 5 Electron diffraction patterns taken down the [001] zone axis for (a) $\mathrm{Ca}_{0.9} \mathrm{La}_{0.067} \mathrm{ZrO}_{3}$ indexed to $\mathrm{Pcmn}$, (b) $\mathrm{Sr}_{0.9} \mathrm{La}_{0.067} \mathrm{ZrO}_{3}$ indexed to $\mathrm{Pbnm}$ and (c) $\mathrm{Ba}_{0.08} \mathrm{La}_{0.053} \mathrm{ZrO}_{3}$ indexed to $\mathrm{Pm} 3 \mathrm{~m}$.

contraction $(6.04 \%$, equivalent to $0.25 \AA)$, which was not observed in our analysis. It is unlikely that such contraction could be induced by cation substitution, and if the lattice parameter reduction is taken as reported for $x=0 \rightarrow 0.02 \rightarrow$ $0.04 \rightarrow 0.06 \rightarrow 0.08 \rightarrow 0.1$, the associated reduction in the cubic parameter would be equivalent to $6.04 \% \rightarrow 0.37 \% \rightarrow$ $0.18 \% \rightarrow 0.17 \% \rightarrow 0.02 \%$. Errors are not reported by the authors, and it is likely that the $0.02 \%$ reduction from $x=0.08$ $\rightarrow 0.1$ may be within error, and a solubility limit of La in the solid-solution had also been reached in this case.

Electron diffraction was further used to confirm the space group symmetry of each doped composition, with SAED patterns taken with the electron beam orientated down the [001] axis presented for the $\mathrm{Ca}_{0.9} \mathrm{La}_{0.067} \mathrm{ZrO}_{3}, \mathrm{Sr}_{0.9} \mathrm{La}_{0.067} \mathrm{ZrO}_{3}$ and $\mathrm{Ba}_{0.08} \mathrm{La}_{0.053} \mathrm{ZrO}_{3}$ compositions presented in Fig. $5 \mathrm{a}$, b and c, respectively. In each instance, the patterns from these doped samples were found to index to the counterpart parent end member, namely Pcmn for $\mathrm{CaZrO}_{3}, \mathrm{Pbnm}$ for $\mathrm{SrZrO}_{3}$ and $\mathrm{Pm} \overline{\mathrm{3}} \mathrm{m}$ for $\mathrm{BaZrO}_{3}$. The presence of La within powdered specimens of the $\mathrm{Ca}_{0.9} \mathrm{La}_{0.067} \mathrm{ZrO}_{3}, \quad \mathrm{Sr}_{0.9} \mathrm{La}_{0.06} \mathrm{ZrO}_{3}$ and $\mathrm{Ba}_{0.92} \mathrm{La}_{0.053} \mathrm{ZrO}_{3}$ samples was further confirmed using TEM/EELS. BF micrographs and corresponding EELS spectra are presented within ESI Fig. 3, 4 and $5 . \dagger$

\subsection{In situ ion irradiation}

Values of critical amorphisation fluences for all samples are presented in Fig. 6a, with fits from the nonlinear least-squares refinements using eqn (1) also presented. Included within Fig. 6a are values for $\mathrm{SrZrO}_{3}$ at $473 \mathrm{~K}$, and $\mathrm{BaZrO}_{3}$ at $673 \mathrm{~K}$, at which amorphisation was not achieved, presented as grey data points. These values lie above the calculated $T_{\mathrm{c}}$ curves for the respective samples, suggesting these irradiations took place at temperatures that prevented amorphisation. Values for $F_{\mathrm{c} 0}, T_{\mathrm{c}}$ and $E_{\mathrm{a}}$, calculated using eqn (1), and $E_{\mathrm{th}}$ and $E_{\text {irr }}$ values, calculated using eqn (2), are reported in Table 3. Calculated values for $T_{\mathrm{c}}$ are also shown graphically in Fig. $6 \mathrm{~b}$.

Firstly, the end member compositions have $T_{\mathrm{c}}$ values with the trend of $\mathrm{SrZrO}_{3}(440 \mathrm{~K})<\mathrm{CaZrO}_{3}(623 \mathrm{~K})<\mathrm{BaZrO}_{3}(675 \mathrm{~K})$. This was similar to the titanate compositions of $\mathrm{CaTiO}_{3}, \mathrm{SrTiO}_{3}$ and $\mathrm{BaTiO}_{3}$ reported by Meldrum et al. ${ }^{48}$ which showed a $T_{\mathrm{c}}$ relationship of $\mathrm{SrTiO}_{3}(425 \mathrm{~K})<\mathrm{CaTiO}_{3}(440 \mathrm{~K})<\mathrm{BaTiO}_{3}(550 \mathrm{~K})$. In all instances, the $T_{\mathrm{c}}$ values for the zirconate end members calculated in this study were appreciably higher than their A-site titanate equivalents. While Meldrum et al. ${ }^{48}$ employed a $1 \mathrm{MeV}$ $\mathrm{Kr}^{+}$ion beam as opposed to the $400 \mathrm{keV} \mathrm{Kr}{ }^{+}$beam utilised in the present study, a significant difference in $T_{\mathrm{c}}$ under the two different conditions would not be expected considering the SRIM calculations discussed previously, although the temperature specific $F_{\mathrm{c}}$ values may be altered. Most comparisons within the present study are with those using $800 \mathrm{keV}$ to $1 \mathrm{MeV}$ $\mathrm{Kr}^{+}$ion beams, and while a significant difference in calculated $T_{\mathrm{c}}$ values is not expected, the difference in the ion beam used should be noted. This includes the studies of A-site deficient systems previously reported. ${ }^{62-64}$

The relationship between titanates and zirconates differs from those in the pyrochlore system, in which zirconates such as $\mathrm{La}_{2} \mathrm{Zr}_{2} \mathrm{O}_{7}$ and $\mathrm{Gd}_{2} \mathrm{Zr}_{2} \mathrm{O}_{7}$ show a remarkable tolerance for radiation damage compared to their titanate counterparts. ${ }^{82-85}$ These relationships are governed by anti-site defect formation energies and phase transitions to the defect fluorite (a)

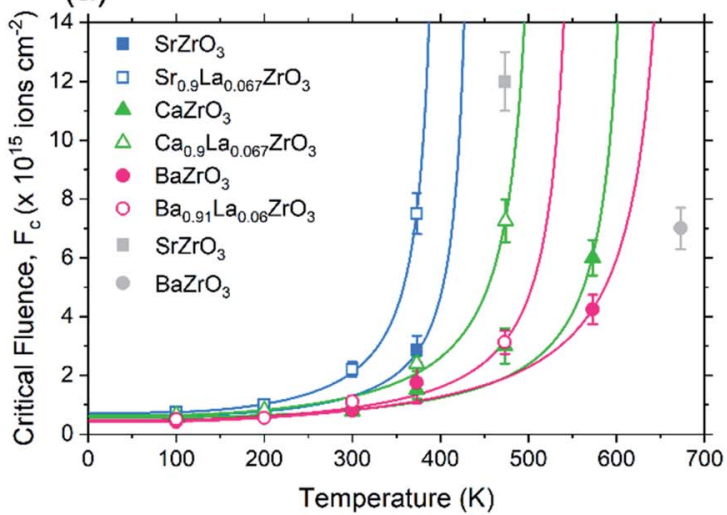

(b)

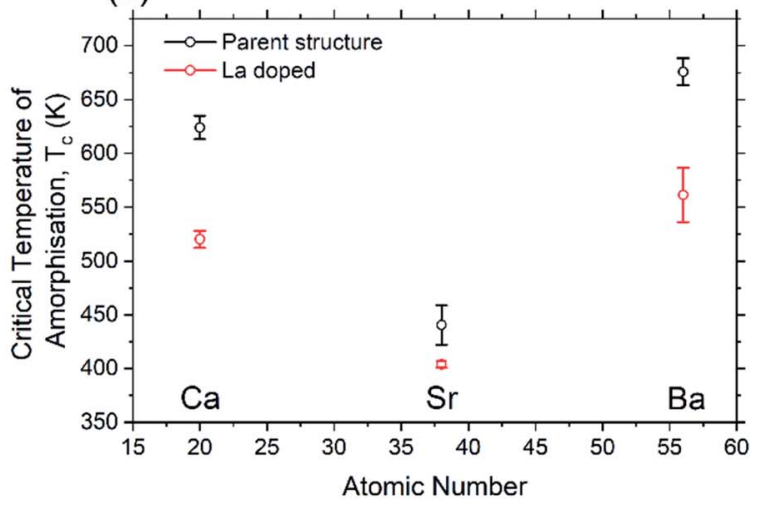

Fig. 6 (a) Values of the critical fluence of amorphisation, $F_{c}$ at given temperatures. Fits based on eqn (1) are also presented. The grey solid square refers to $\mathrm{SrZrO}_{3}$ fluence at $473 \mathrm{~K}$ and the grey solid circle to a $\mathrm{BaZrO}_{3}$ fluence at $673 \mathrm{~K}$; amorphisation was not achieved in either of these cases. (b) Values of the critical temperature of amorphisation, $T_{\mathrm{c}}$ for each sample plotted with atomic number. Each $T_{\mathrm{c}}$ value is located above the respective "Ca", "Sr" and "Ba" markers referring to pristine and $\mathrm{La}$ doped $\mathrm{CaZrO}_{3}, \mathrm{SrZrO}_{3}$ and $\mathrm{BaZrO}_{3}$ samples. Pristine samples are presented in black, and La doped in red. 
Table 3 Fitting parameters for calculation of critical temperatures of amorphisation, $T_{\mathrm{c}}{ }^{a}$

\begin{tabular}{|c|c|c|c|c|c|}
\hline Sample & \multicolumn{3}{|l|}{ From eqn (1) } & \multicolumn{2}{|c|}{ From eqn (2) } \\
\hline $\mathrm{Sr}_{0.9} \mathrm{La}_{0.067} \mathrm{ZrO}_{3}$ & $7.2(3)$ & $404(3)$ & $0.042(4)$ & $0.926(8)$ & $1.167(8)$ \\
\hline $\mathrm{CaZrO}_{3}$ & $5.8(9)$ & $623(11)$ & $0.060(8)$ & $1.42(3)$ & $1.79(3)$ \\
\hline $\mathrm{Ca}_{0.9} \mathrm{La}_{0.067} \mathrm{ZrO}_{3}$ & $6.2(8)$ & $520(8)$ & $0.041(5)$ & $1.19(2)$ & $1.50(2)$ \\
\hline
\end{tabular}

${ }^{a}$ Critical amorphisation fluence at $0 \mathrm{~K} F_{\mathrm{co}}\left(\times 10^{14}\right.$ ions per $\left.\mathrm{cm}^{2}\right)$, critical temperature of amorphisation, $T_{\mathrm{c}}(\mathrm{K})$, activation energy $E_{\mathrm{a}}(\mathrm{eV})$, activation energy for thermally assisted recovery $E_{\mathrm{th}}(\mathrm{eV})$ and activation energy for irradiation assisted recovery $E_{\text {irr }}(\mathrm{eV})$.

structure, ${ }^{35,86}$ processes that are not replicated within perovskites. The calculated $T_{\mathrm{c}}$ values suggest the specific A-site cation plays a larger role than structure within perovskite systems. For the titanate systems, $T_{\mathrm{c}}$ values take the structural trend $P m \overline{3} m<$ $P b n m<I 4 / \mathrm{mcm}$, while for the zirconates the trend is $P b n m=$ $P c m n<P m \overline{3} m$, showing no relationship with relative symmetry, tolerance factor ${ }^{50}$ or A/B site radii ratio. A recent study by Meena et $a l .{ }^{87}$ suggests a relative increase in the ionic-nature of bonding for $\mathrm{SrTiO}_{3}>\mathrm{BaTiO}_{3}>\mathrm{CaTiO}_{3}$, which does not follow the $T_{\mathrm{c}}$ trends observed. With regard to displacement energy, $E_{\mathrm{d}}$, a variety of values through both experimental and theoretical routes have been determined, but no conclusive values can be assigned to these systems. While values have been determined for $\mathrm{CaZrO}_{3}$, the authors noted the reported cation values were appreciably lower than previously measured oxide samples, ${ }^{\mathbf{8}}$ preventing comparison between titanate and zirconate systems. It is thus hypothesised that the flexible nature of the $\mathrm{Ti}(\mathrm{III}) / \mathrm{Ti}(\mathrm{IV})$ B-site, in comparison with the highly-refractory $\operatorname{Zr}(\mathrm{Iv})$, may promote defect mobility and an increased tolerance for oxygen displacements at higher temperatures. This could take the form of $\mathrm{ATi}_{1-x}{ }^{4+} \mathrm{Ti}_{x}{ }^{3+} \mathrm{O}_{3-\delta}$ phases being induced during irradiation, whereas zirconium reduction is far less likely, and the resultant oxygen deficiency is harder to accommodate. This may also be the case for the as produced pristine materials, as has been observed for (Ba, $\mathrm{Sr}, \mathrm{Ca}) \mathrm{TiO}_{3}$ perovskites. $^{89}$

For the La-doped samples, similar trends as with doped titanate perovskites are observed. For instance, a decrease in $T_{\mathrm{c}}$ between $\mathrm{CaTiO}_{3}$ and $\mathrm{Ca}_{0.9} \mathrm{La}_{0.067} \mathrm{TiO}_{3}$ is reported of $\approx 140 \mathrm{~K},{ }^{63}$ while a drop of $\approx 100 \mathrm{~K}$ is reported here for the counterpart zirconates. Similarly, a reduction in $T_{\mathrm{c}}$ of $\approx 90 \mathrm{~K}$ is reported between $\mathrm{SrTiO}_{3}$ and $\mathrm{Sr}_{0.85} \mathrm{La}_{0.1} \mathrm{TiO}_{3}$ (ref. 62) and a decrease of $\approx 40 \mathrm{~K}$ within the zirconate counterparts is found in the present investigation (note that the titanate contains 3.33 mol\% greater La content than within our study). In direct comparison, the titanates exhibit a lower $T_{\mathrm{c}}$ for both $\mathrm{Ca}$ and $\mathrm{Sr}$ based end members, with $\mathrm{Ca}_{0.9} \mathrm{La}_{0.067} \mathrm{TiO}_{3}(<300 \mathrm{~K})>\mathrm{Ca}_{0.9} \mathrm{La}_{0.067} \mathrm{ZrO}_{3}(520$ $\mathrm{K})$ and $\mathrm{Sr}_{0.9} \mathrm{La}_{0.067} \mathrm{TiO}_{3}(308 \mathrm{~K})>\mathrm{Sr}_{0.9} \mathrm{La}_{0.067} \mathrm{ZrO}_{3}(402 \mathrm{~K})$. No structural changes were induced between the parent and doped samples in any of these cases. It is possible that La has an intrinsically higher $E_{\mathrm{d}}$ than each parent A-site constituent. Considering the observations reported regarding the $\mathrm{Sr}_{1-x} \mathrm{La}_{2 x}$ ${ }_{3} \mathrm{TiO}_{3}$ and $\mathrm{Ca}_{1-x} \mathrm{La}_{2 x / 3} \mathrm{TiO}_{3}$ systems, in which La doping of $x>$ 0.4 samples increased $T_{\mathrm{c}}$ with regard to the parent end member, it seems unlikely that an increased A-site displacement energy is the sole cause of the trends observed in these zirconates. Values for $\mathrm{La}$ within $\mathrm{La}_{2} \mathrm{Zr}_{2} \mathrm{O}_{7}$ are reported to be similar to $\mathrm{Ba}, \mathrm{Sr}$ and Ca in perovskite systems, namely $E_{\mathrm{d}}=65 \pm 20 \mathrm{eV},{ }^{90-92}$ providing further evidence against such a conclusion. As is reported in Table 3, the activation energies for both thermal and irradiation assisted recovery are reduced for all doped samples with relation to their respective end member counterparts. This does suggest that increased defect migration and ionic diffusion may be the cause of the reduction in $T_{\mathrm{c}}$ for doped samples, however direct measurement of such characteristics would be required to prove this hypothesis.

Several studies on the effects of doping and sintering characteristics on perovskite systems have been reported, and the resultant consequences on cation and oxygen deficiency. ${ }^{93-96}$ Within studies of $\mathrm{Sr}_{1-x} \mathrm{La}_{2 x / 3} \mathrm{TiO}_{3}$ and $\mathrm{Ca}_{1-x} \mathrm{La}_{2 x / 3} \mathrm{TiO}_{3},{ }^{62,63}$ samples were sintered at $1573 \mathrm{~K}$ in air, while the bulk ion irradiation study showing increased room temperature resistance to amorphisation for $0.2 \leq x \leq 0.4$ used pellets sintered at 1673 K. ${ }^{64}$ Oxygen loss has been shown to rapidly increase with sintering temperature in the A-site deficient $\mathrm{Sr}_{0.85} \mathrm{La}_{0.1} \mathrm{TiO}_{3}$ system, even at temperatures of $1473 \mathrm{~K}$ in flowing $\mathrm{O}_{2} \cdot{ }^{97}$ This has the consequence of causing significant reductions in the activation energy, $E_{\mathrm{a}}$, for bulk ionic conductivity, which can be readily linked to the concentration and mobility of oxygen vacancies within the system. Akin et al. ${ }^{97}$ report a reduction in $E_{\text {a }}$ from $0.97 \mathrm{eV}$ for $\mathrm{SrTiO}_{3}$ sintered at $1723 \mathrm{~K}$ in $\mathrm{O}_{2}$ to $0.16 \mathrm{eV}$ for $\mathrm{Sr}_{0.85} \mathrm{La}_{0.1} \mathrm{TiO}_{3}$ sintered under the same conditions. This decreased energy requirement for oxygen vacancy mobility may lead to increased recovery rates, particularly at elevated temperatures, that lead to reductions in $T_{\mathrm{c}}$. This does not take into consideration sintering temperatures. $E_{\mathrm{a}}$ values of $1.64 \mathrm{eV}$ and $1.79 \mathrm{eV}$ are reported in $\mathrm{Sr}_{0.85} \mathrm{La}_{0.1} \mathrm{TiO}_{3}$ sintered at $1473 \mathrm{~K}$ under $\mathrm{O}_{2}$ and $\mathrm{N}_{2}$, respectively, and values of $0.16 \mathrm{eV}$ at $1723 \mathrm{~K}$ in $\mathrm{O}_{2}$. They report the same sample sintered at $1723 \mathrm{~K}$ in $\mathrm{N}_{2}$ as being too conductive to measure even at $10 \mathrm{~K}$, suggesting an even lower $E_{\mathrm{a}}$ value for this sintering condition. It may be that such effects regarding sintering atmosphere and temperature translate to radiation damage kinetics, but it should be noted the effects of sintering temperature are not as dramatic in $\mathrm{SrTiO}_{3}$. While these are feasible explanations, such mechanisms have not been tested in the present study and it is not possible to transfer this theory to the zirconates studied here, 


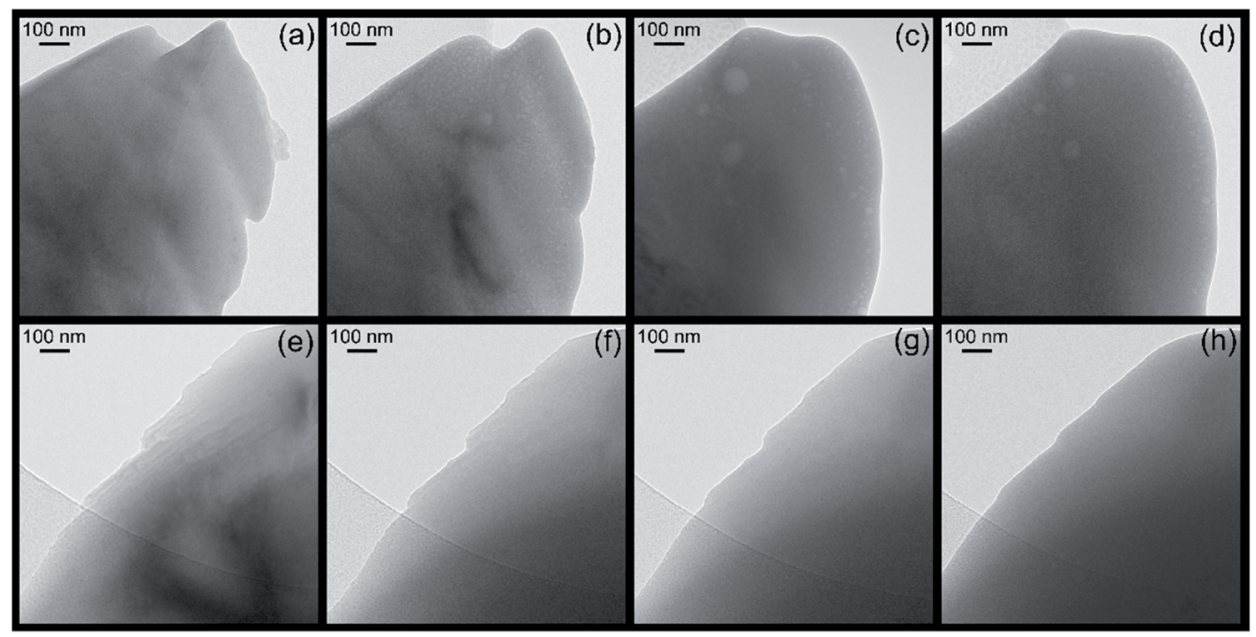

Fig. $7 \mathrm{BF}$ micrographs of $\mathrm{Ca}_{0.9} \mathrm{La}_{0.067} \mathrm{ZrO}_{3}$ irradiated at $473 \mathrm{~K}$ to a fluence of (a) $0 F_{\mathrm{c}}$ (b) $0.3 F_{c}$ (c) $0.8 F_{\mathrm{c}}$ and (d) $F_{\mathrm{c}}$ and at $100 \mathrm{~K}$ to fluences of (e) $O F_{c}$ (f) $0.3 F_{c}$ (g) $0.8 F_{c}$ and $(\mathrm{h}) F_{c}$

other than through empirical observations of the similarities in $T_{\mathrm{c}}$. Based on the $T_{\mathrm{c}}$ observations made, it is proposed that a similar mechanism leads to the reductions in $T_{\mathrm{c}}$ for doped samples, i.e. less oxygen deficiency within a zirconate system as compared to a titanate. Studying bulk pellets of A-site deficient samples sintered under various temperatures and atmospheres may elucidate this behaviour, and studies are now taking place in this regard.

Fig. 7 presents under-focus $(\approx 500 \mathrm{~nm})$ BFTEM micrographs of an irradiated grain of the $\mathrm{Ca}_{0.9} \mathrm{La}_{0.067} \mathrm{ZrO}_{3}$ sample at $473 \mathrm{~K}$ (Fig. 7a-d) and $100 \mathrm{~K}$ (Fig. 7e-h). At a fluence of 0.3 of the critical fluence for amorphisation $\left(0.3 F_{c}\right.$; Fig. $\left.7 \mathrm{~b}\right)$ at $473 \mathrm{~K}$, a high density of light circular contrast regions was observed. With increased fluence to $0.8 F_{\mathrm{c}}(\mathrm{Fig} .7 \mathrm{c})$, these circular regions grew in size whilst decreasing in areal density, suggesting a migration and agglomeration of these features. On first observation, it could be argued this was the result of $\mathrm{Kr}$ bubble formation, with the elevated temperature promoting $\mathrm{Kr}$ migration and agglomeration into bubbles. Forming $\mathrm{Kr}$ bubbles in ceramic oxide samples normally requires the implantation of on the order of $10^{15}$ to $10^{16}$ ions per $\mathrm{cm}^{2}$, and considering the $<5 \% \mathrm{Kr}$ retention (as predicted by SRIM) under these conditions it is unlikely this contrast was the result of $\mathrm{Kr}$ bubbles. Furthermore, previously observed bubble sizes in ceramic oxide systems are on the order of $\approx 2 \mathrm{~nm}$, even at these elevated temperatures. ${ }^{98-101}$ Therefore, it is likely these areas are void-type defects, i.e. a high concentration of irradiation induced vacancies, with the elevated temperatures allowing for void growth and agglomeration. It can be qualitatively observed that at $0.8 F_{\mathrm{c}}$ (Fig. $7 \mathrm{c}$ ), larger voids were present and in higher density than at the amorphisation fluence, $F_{\mathrm{c}}$ (Fig. 7d). This process was likely driven by void migration and growth toward the grain edges, with the voids annihilating at the surfaces that act as a defect sink. While these observations evidence the microstructural build-up of defects under irradiation, such defects do not appear to have significantly affected the increased recovery rates onset by increased thermal energy, with an amorphisation fluence of $F_{\mathrm{c}}=7.3 \pm 0.8 \times 10^{15}$ ions per $\mathrm{cm}^{2}$ for this sample at $473 \mathrm{~K}$.

The morphology of the grain was also observed to change, with the grain edges smoothing with increasing fluence compared to the irregularly shaped pristine grain. This may have been due to material sputtering, however grain swelling has been reported in various ceramics under ion irradiation, and it may be that a combination of irradiation and temperature induced migration induced a "flow" of material that induced such a change in morphology. In contrast, at $100 \mathrm{~K}$, no void formation was observed at any fluence (Fig. 7e-h), in a similar manner to void formation in steels that requires elevated temperatures. Indeed, it may be that the increased recovery rates at $473 \mathrm{~K}$ were required to induce a significant density of vacancy defects to allow for the formation of observable voids, or that at $100 \mathrm{~K}$ there is insignificant defect mobility to allow for the required agglomeration. Similarly, changes in grain morphology at this temperature were severely reduced, however this may have resulted from either reduced temperature preventing "flow" or reduced sputtering at a lower fluence. Such effects were not observed at room temperature or below in any samples, confirming this was a thermally driven process.

\section{Conclusions}

Solid-solutions of single-phase $\mathrm{Ca}_{0.9} \mathrm{La}_{0.067} \mathrm{ZrO}_{3}$ and $\mathrm{Sr}_{0.9^{-}}$ $\mathrm{La}_{0.067} \mathrm{ZrO}_{3}$ were produced, and the solubility limit of $\mathrm{La}$ in $\mathrm{BaZrO}_{3}$, through the compositional formula $\mathrm{Ba}_{1-x} \mathrm{La}_{2 x / 3} \mathrm{ZrO}_{3}$, was found at $x=0.08$. Each of these samples maintained their parent end member structure, namely Pcmn, Pbnm and $P m \overline{3} m$ for $\mathrm{CaZrO}_{3}, \mathrm{SrZrO}_{3}$ and $\mathrm{BaZrO}_{3}$, respectively. Values of the critical temperature of amorphisation, $T_{\mathrm{c}}$, were calculated of $\approx 440 \mathrm{~K}, \approx 623 \mathrm{~K}$ and $\approx 675 \mathrm{~K}$ for $\mathrm{SrZrO}_{3}, \mathrm{CaZrO}_{3}$ and $\mathrm{BaZrO}_{3}$, respectively, compared to $\approx 404 \mathrm{~K}, \approx 520 \mathrm{~K}$ and $\approx 621 \mathrm{~K}$ for the La doped counterparts $\left(\mathrm{Ba}_{0.08} \mathrm{La}_{0.053} \mathrm{ZrO}_{3}\right.$ for the Ba sample). The response of the materials to ion irradiation were 
rationalised by linking to studies regarding ionic conductivity within doped perovskite titanates, and in particular oxygen vacancy mobility within such systems. Void formation, migration and agglomeration at elevated temperatures was observed, including changes in grain morphology, mechanisms that were not observed below room temperature.

\section{Conflicts of interest}

There are no conflicts of interest to declare.

\section{Acknowledgements}

SML, RC and CLC would like to acknowledge EPSRC for funding under grant number EP/N017374/1. GG would like to acknowledge funding under grant number EP/M028283/1. This research utilised the HADES/MIDAS facility ${ }^{\mathbf{1 0 2}}$ at the University of Sheffield established with financial support from EPSRC and BEIS, under grant EP/T011424/1. We wish to acknowledge the Henry Royce Institute for Advanced Materials, funded through EPSRC grants EP/R00661X/1，EP/S019367/1，EP/P02470X/1 and EP/ P025285/1, for JEOL JEM-F200 access at Royce@Sheffield.

\section{Notes and references}

1 A. J. Jacobson, Materials for Solid Oxide Fuel Cells, Chem. Mater., 2010, 22(3), 660-674, DOI: 10.1007/978-0-38768815-2_12.

2 R. Pornprasertsuk, O. Kosasang, K. Somroop, M. Horprathum, P. Limnonthakul, P. Chindaudom and S. Jinawath, Proton Conductivity of Y-Doped $\mathrm{BaZrO}_{3}$ : Pellets and Thin Films, Solid State Sci., 2011, 13(7), 14291437, DOI: 10.1016/j.solidstatesciences.2011.04.015.

3 V. Vashook, L. Vasylechko, N. Trofimenko, M. Kuznecov, P. Otchik, J. Zosel and U. Guth, A-Site Deficient Perovskite-Type Compounds in the Ternary CaTiO3LaCrO3-La2/3TiO3 System, J. Alloys Compd., 2006, 419(12), 271-280, DOI: 10.1016/j.jallcom.2005.09.063.

4 V. Vashook, L. Vasylechko, M. Knapp, H. Ullmann and U. Guth, Lanthanum Doped Calcium Titanates: Synthesis, Crystal Structure, Thermal Expansion and Transport Properties, J. Alloys Compd., 2003, 354, 13-23, DOI: 10.1016/S0925-8388(02)01345-2.

5 F. Azough, W. Wang and R. Freer, The Crystal Structure of $\mathrm{LaAlO}_{3}$-Stabilized $\mathrm{La}_{2 / 3} \mathrm{TiO}_{3}$ Ceramics: An HRTEM Investigation, J. Am. Ceram. Soc., 2009, 92(9), 2093-2098, DOI: $10.1111 / \mathrm{j} .1551-2916.2009 .03161 . x$.

6 I.-S. Kim, W.-H. Jung, Y. Inaguma, T. Nakamure and M. Itoh, Dielectric Properties of A-Site Deficient PeroskiteType Lanthanum-Calcium-Titanium Oxide Solid Solution System, Mater. Res. Bull., 1995, 30(3), 307-316, DOI: 10.1016/0025-5408(94)00142-1.

7 I. Levin, T. G. Amos, S. M. Bell, L. Farber, T. a. Vanderah, R. S. Roth and B. H. Toby, Phase Equilibria, Crystal Structures, and Dielectric Anomaly in the $\mathrm{BaZrO}_{3}-\mathrm{CaZrO}_{3}$ System, J. Solid State Chem., 2003, 175(2), 170-181, DOI: 10.1016/S0022-4596(03)00220-2.
8 A. K. Jena, A. Kulkarni and T. Miyasaka, Halide Perovskite Photovoltaics: Background, Status, and Future Prospects, Chem. Rev., 2019, 119(5), 3036-3103, DOI: 10.1021/ acs.chemrev.8b00539.

$9 \mathrm{H}$. Fu, Review of Lead-Free Halide Perovskites as LightAbsorbers for Photovoltaic Applications: From Materials to Solar Cells, Sol. Energy Mater. Sol. Cells, 2019, 193, 107132, DOI: 10.1016/j.solmat.2018.12.038.

10 S.-R. Bae, Q. V. Le and S.-Y. Kim, Recent Advances toward High Efficiency Halide Perovskite Light Emitting Diodes: Review and Perspective, Small Methods, 2018, 2(1700419), 24-43, DOI: 10.31613/ceramist.2018.21.1.03.

11 K. Wang, S. Wang, S. Xiao and Q. Song, Recent Advances in Perovskite Micro- and Nanolasers, Adv. Opt. Mater., 2018, 6(1800278), 1-27, DOI: 10.1002/adom.201800278.

12 M. M. Stylianakis, T. Maksudov, A. Panagiotopoulos, G. Kakavelakis and K. Petridis, Inorganic and Hybrid Perovskite Based Laser Devices: A Review, Materials, 2019, 12(859), 1-28, DOI: 10.3390/ma12060859.

13 IAEA, Viability of Inert Matrix Fuel in Reducing Plutonium Amounts in Reactors, Vienna, 2006.

14 M. Danaie, D. Kepaptsoglou, Q. M. Ramasse, C. Ophus, K. R. Whittle, S. M. Lawson, S. Pedrazzini, N. P. Young, P. A. J. Bagot and P. D. Edmondson, Characterization of Ordering in A-Site Deficient Perovskite $\mathrm{Ca}_{1-\mathrm{x}} \mathrm{La}_{2 \times / 3} \mathrm{TiO}_{3}$ Using STEM/EELS, Inorg. Chem., 2016, 55, 9937-9948, DOI: 10.1021 /acs.inorgchem.6b02087.

15 S. Pedrazzini, A. J. London, B. Gault, D. Saxey, S. Speller, C. R. M. Grovenor, M. Danaie, M. P. Moody, P. D. Edmondson and P. A. J. Bagot, Nanoscale Stoichiometric Analysis of a High-Temperature Superconductor by Atom Probe Tomography, Microsc. Microanal., 2017, 23(2), 414-424, DOI: 10.1017/ S1431927616012757.

16 R. Biswal, D. Behera, D. Kanjilal, P. V. Satyam and N. C. Mishra, Evolution of Superconducting and Normal State Properties of $\mathrm{YBa}_{2} \mathrm{Cu}_{3} \mathrm{O}_{7-\mathrm{y}}$ Thick Films under 200 MeV Ag Ion Irradiation, Phys. C, 2012, 480, 98-101, DOI: 10.1016/j.physc.2012.05.012.

17 J. C. Barbour, E. L. Venturini, D. S. Ginley and J. F. Kwak, Irradiation Effects in High Temperature Superconductors, Nucl. Instrum. Methods Phys. Res., Sect. B, 1992, B65, 531538, DOI: 10.1016/0168-583X(92)95100-6.

18 A. A. Gapud, N. T. Greenwood, J. A. Alexander, A. Khan, K. J. Leonard, T. Aytug, F. A. List, M. W. Rupich and Y. Zhang, Irradiation Response of Commercial, High-Tc Superconducting Tapes: Electromagnetic Transport Properties, J. Nucl. Mater., 2015, 462, 108-113, DOI: 10.1016/j.jnucmat.2015.03.047.

19 A. Jostons and S. E. Kesson, The Synroc Strategy for HLW Management, Mineral. Mag., 1993, 58A, 458-459, DOI: 10.1180/minmag.1994.58a.1.238.

20 J. P. Evans, K. A. Boult, E. L. Paige and J. A. C. Marples, The Preparation of Fully Active Synroc and Its Radiation Stability Progress Report, Harwell, UK, 1986.

21 J. L. Woolfrey, D. J. Reeve and K. D. Cassidy, Accelerated Irradiation Testing of SYNROC and Its Constituent 
Minerals Using Fast Neutrons, J. Nucl. Mater., 1982, 108/ 109, 739-747.

22 K. Reeve and J. Woolfrey, Accelerated Irradiation Testing of Synroc Using Fast Neutrons - First Results on Barium Hollandite, Perovskite and Synroc B, J. Aust. Ceram. Soc., 1980, 16(1), 10-15.

23 M. J. Hambley, S. Dumbill, E. R. Maddrell and S. C. R, Characterisation of 20-Year-Old Pu 238 -Doped Synroc C, MRS Proceedings, 2008, 373, DOI: 10.1557/PROC-1107-373.

24 A. E. Ringwood, V. M. Oversby, S. E. Kesson, W. Sinclair, N. Ware, W. Hibberson and A. Major, Immobilization of High-Level Nuclear Reactor Wastes in SYNROC: A Current Appraisal, Nucl. Chem. Waste Manage., 1981, 2(4), 287305, DOI: 10.1016/0191-815X(81)90055-3.

25 E. R. Vance, G. R. Lumpkin, M. L. Carter, D. J. Cassidy, C. J. Ball, R. A. Day and B. D. Begg, Incorporation of Uranium in Zirconolite (CaZrTi2O7), J. Am. Ceram. Soc., 2004, 85(7), 1853-1859, DOI: 10.1111/j.11512916.2002.tb00364.x.

26 R. W. Cheary and A. A. Coelho, A Site Occupancy Analysis of Zirconolite $\mathrm{CaZr}_{\mathrm{x}} \mathrm{Ti}_{3-\mathrm{x}} \mathrm{O}_{7}$, Phys. Chem. Miner., 1997, 24, 447454.

27 A. A. Coelho, R. W. Cheary and K. L. Smith, Analysis and Structural Determination of Nd-Substituted Zirconolite4M, J. Solid State Chem., 1997, 129(2), 346-359, DOI: 10.1006/jssc.1996.7263.

28 D. J. Bailey, S. M. Lawson, S. K. Sun, M. C. Stennett, T. Lee, B. Ravel, C. L. Corkhill, J. Heo and N. C. Hyatt, A New Approach to the Immobilisation of Technetium and Transuranics: Co-Disposal in a Zirconolite Ceramic Matrix, J. Nucl. Mater., 2019, 528, 151885, DOI: 10.1016/ j.jnucmat.2019.151885.

29 S. K. Sun, M. C. Stennett, C. L. Corkhill and N. C. Hyatt, Reactive Spark Plasma Synthesis of $\mathrm{CaZrTi}_{2} \mathrm{O}_{7}$ Zirconolite Ceramics for Plutonium Disposition, J. Nucl. Mater., 2018, 500, 11-14, DOI: 10.1016/j.jnucmat.2017.12.021.

30 J. Squire, E. R. Maddrell, N. C. Hyatt and M. C. Stennett, Influence of Lubricants and Attrition Milling Parameters on the Quality of Zirconolite Ceramics, Consolidated by Hot Isostatic Pressing, for Immobilization of Plutonium, Int. J. Appl. Ceram. Technol., 2015, 12(S2), E92-E104, DOI: 10.1111/ijac.12239.

31 C. Davoisne, M. C. Stennett, N. C. Hyatt, N. Peng, C. Jeynes and W. E. Lee, Krypton Irradiation Damage in Nd-Doped Zirconolite and Perovskite, J. Nucl. Mater., 2011, 415(1), 67-73, DOI: 10.1016/j.jnucmat.2011.05.043.

32 H. Mitamura, S. Matsumoto, T. Miyazaki, T. J. White, K. Nukaga, Y. Togashi, T. Sagawa, S. Tashiro, D. M. Levins and A. Kikuchi, Self-Irradiation Damage of a Curium-Doped Titanate Ceramic Containing Sodium-Rich High-Level Nuclear Waste, J. Am. Ceram. Soc., 1990, 73(11), 3433-3441, DOI: 10.1111/j.11512916.1990.tb06472.x.

33 H. Mitamura, S. Matsumoto, T. Tsuboi, E. R. Vance, B. D. Begg and K. P. Hart, Alpha-Decay Damage of CmDoped Perovskite, MRS Proceedings, 1995, 353, 1405-1412, DOI: 10.1557/PROC-353-1405.
34 M. D. Strachan, R. D. Scheele, J. P. Icenhower, E. C. Buck, A. E. Kozelisky, R. L. Sell, R. J. Elovich and W. C. Buckmiller, Radiation Damage Effects in Candidate Ceramics for Plutonium Immobilization, Final Report, 2004.

35 K. Trachenko, M. Pruneda, E. Artacho and M. Dove, Radiation Damage Effects in the Perovskite $\mathrm{CaTiO}_{3}$ and Resistance of Materials to Amorphization, Phys. Rev. B: Condens. Matter Mater. Phys., 2004, 70(13), 134112, DOI: 10.1103/PhysRevB.70.134112.

36 K. L. Smith, N. J. Zaluzec and G. R. Lumpkin, In Situ Studies of Ion Irradiated Zirconolite, Pyrochlore and Perovskite, $J$. Nucl. Mater., 1997, 250(1), 36-52, DOI: 10.1016/S00223115(97)00237-7.

37 K. R. Whittle, G. R. Lumpkin, M. G. Blackford, R. D. Aughterson, K. L. Smith and N. J. Zaluzec, Ion-Beam Irradiation of Lanthanum Compounds in the Systems La ${ }_{2} \mathrm{O}_{3} \mathrm{Al}_{2} \mathrm{O}_{3}$ and $\mathrm{La}_{2} \mathrm{O}_{3} \mathrm{TiO}_{2}$, J. Solid State Chem., 2010, 183(10), 2416-2420, DOI: 10.1016/j.jssc.2010.07.033.

38 G. R. Lumpkin, M. Colella, K. L. Smith, R. H. Mitchell and A. O. Larsen, Chemical Composition, Geochecmial Alteration, and Radiation Damage Effects in Natural Perovskite, MRS Proceedings, 1998, 506, 207-214.

39 B. S. Thomas, N. a. Marks and B. D. Begg, Developing Pair Potentials for Simulating Radiation Damage in Complex Oxides, Nucl. Instrum. Methods Phys. Res., Sect. B, 2005, 228(1-4), 288-292, DOI: 10.1016/j.nimb.2004.10.058.

40 J. Rankin, L. W. Hobbs, L. A. Boatner and C. W. White, An in Situ Annealing Study of Lead Implanted Single Crystal Calcium Titanate, Nucl. Instrum. Methods Phys. Res., Sect. B, 1988, 32(1-4), 28-31, DOI: 10.1016/0168-583X(88)901747.

41 M. J. Zhuo, L. Yan, E. G. Fu, Y. Q. Wang, a. Misra, M. Nastasi, B. P. Uberuaga and Q. X. Jia, Phase Transformations and Defect Clusters in Single Crystal SrTiO3 Irradiated at Different Temperatures, J. Nucl. Mater., 2013, 442(1-3), 143-147, DOI: 10.1016/ j.jnucmat.2013.08.046.

42 W. J. Weber, R. C. Ewing, C. R. A. Catlow, T. Diaz de la Rubia, L. W. Hobbs, C. Kinoshita, H. Matzke, A. T. Motta, M. Nastasi, E. K. H. Salje, E. R. Vance and S. J. Zinkle, Radiation Effects in Crystalline Ceramics for the Immobilization of High-Level Nuclear Waste and Plutonium, J. Mater. Res., 1998, 13(6), 1434-1484.

43 C. Sabathier, J. Chaumont and J. C. Krupa, Dose Rate and Temperature Effects in Radiation Disorder Creation in SrTiO3, Nucl. Instrum. Methods Phys. Res., Sect. B, 2002, 196(3-4), 308-314, DOI: 10.1016/S0168-583x(02)01332-0.

44 S. Thevuthasan, W. Jiang, V. Shutthanandan and W. J. Weber, Accumulation of Ion Beam Induced Disorder in Strontium Titanate, Nucl. Instrum. Methods Phys. Res., Sect. B, 2003, 206, 162-165, DOI: 10.1016/S0168-583X(03) 00710-9.

45 W. Sinclair and A. E. Ringwood, Alpha-Recoil Damage in Natural Zirconoite and Perovskite, Geochem. J., 1981, 15, 229-243.

46 J. Won, L. J. Vernon, A. Karakuscu, R. M. Dickerson, M. Cologna, R. Raj, Y. Wang, S. J. Yoo, S.-H. Lee, A. Misra 
and B. P. Uberuaga, The Role of Non-Stoichiometric Defects in Radiation Damage Evolution of $\mathrm{SrTiO}_{3}$, J. Mater. Chem. A, 2013, 1(32), 9235, DOI: 10.1039/c3ta11046j.

47 C. J. Ball, R. G. Blake, D. J. Cassidy and J. L. Woolfrey, Neutron Irradiations Effects in Perovskite $\left(\mathrm{CaTiO}_{3}\right), \mathrm{J}$. Nucl. Mater., 1988, 151, 151-161, DOI: 10.1016/00223115(88)90067-0.

48 A. Meldrum, L. A. Boatner, W. J. Weber and R. C. Ewing, Amorphization and Recrystallization of the $\mathrm{ABO}_{3}$ Oxides, J. Nucl. Mater., 2002, 300, 242-254, DOI: 10.1016/S00223115(01)00733-4.

49 M. Lang, F. Zhang, W. Li, D. Severin, M. Bender, S. Klaumünzer, C. Trautmann and R. C. Ewing, Swift Heavy Ion-Induced Amorphization of $\mathrm{CaZrO}_{3}$ Perovskite, Nucl. Instrum. Methods Phys. Res., Sect. B, 2012, 286, 271276, DOI: 10.1016/j.nimb.2011.12.028.

50 V. M. Goldschmidt, Die Gesetze Der Krystallochemie, Naturwissenschaften, 1926, 14, 477-485, DOI: 10.1007/ BF01507527.

51 A. M. Glazer, The Classification of Tilted Octahedra in Perovskites, Acta Crystallogr., Sect. B: Struct. Crystallogr. Cryst. Chem., 1972, 28(11), 3384-3392, DOI: 10.1107/ S0567740872007976.

52 W. D. Macedo, A. E. Souza, G. T. A. Santos, S. R. Teixeira and E. Longo, Microwave-Assisted Hydrothermal Synthesis Followed by Heat Treatment: A New Route to Obtain $\mathrm{CaZrO}_{3}$, Ceram. Int., 2018, 44, 953-958, DOI: 10.1016/ j.ceramint.2017.10.028.

53 V. P. Dravid, C. M. Sung, M. R. Notis and C. E. Lyman, Crystal Symmetry and Coherent Twin Structure of Calcium Zirconate, Acta Crystallogr., Sect. B: Struct. Crystallogr. Cryst. Chem., 1989, 45(3), 218-227, DOI: 10.1107/S0108768189000856.

54 C. J. Howard, K. S. Knight, B. J. Kennedy and E. H. Kisi, Structural Phase Transitions in Strontium Zirconate Revisited, J. Phys.: Condens. Matter, 2000, 12(45), 677-683, DOI: 10.1088/0953-8984/12/45/101.

55 D. de Ligny and P. Richet, High-Temperature Heat Capacity and Thermal Expansion of and Perovskites, Phys. Rev. B: Condens. Matter Mater. Phys., 1996, 53(6), 3013-3022, DOI: 10.1103/PhysRevB.53.3013.

56 B. J. Kennedy, C. J. Howard and B. C. Chakoumakos, HighTemperature Phase Transitions in SrZrO3, Phys. Solid State, 1999, 59(6), 4023-4027.

57 S. Hasegawa, T. Sugimoto and T. Hashimoto, Investigation of Structural Phase Transition Behavior of $\mathrm{SrZrO}_{3}$ by Thermal Analyses and High-Temperature X-Ray Diffraction, Solid State Ionics, 2010, 181, 1091-1097, DOI: 10.1016/j.ssi.2010.06.035.

58 I. Ahmed, S. G. Eriksson, E. Ahlberg, C. S. Knee, M. Karlsson, A. Matic, D. Engberg and L. Börjesson, Proton Conductivity and Low Temperature Structure of In-Doped BaZrO3, Solid State Ionics, 2006, 177(26-32 SPEC. ISS.), 2357-2362, DOI: 10.1016/j.ssi.2006.05.030.

59 S. Parida, S. K. Rout, L. S. Cavalcante, E. Sinha, M. S. Li, V. Subramanian, N. Gupta, V. R. Gupta, J. A. Varela and E. Longo, Structural Refinement, Optical and Microwave
Dielectric Properties of $\mathrm{BaZrO}_{3}$, Ceram. Int., 2012, 38(3), 2129-2138, DOI: 10.1016/j.ceramint.2011.10.054.

60 D. Han, K. Shinoda, S. Sato, M. Majima and T. Uda, Correlation between Electroconductive and Structural Properties of Proton Conductive Acceptor-Doped Barium Zirconate, J. Mater. Chem. A, 2015, 3(3), 1243-1250, DOI: 10.1039/c4ta05701e.

61 E. R. Vance, J. V. Hanna and J. H. Hadley, Cation Vacancies in Perovskites Doped with La and Gd, Adv. Appl. Ceram., 2012, 111(1), 94-98, DOI: 10.1179/ $1743676111 Y .0000000037$.

62 K. L. Smith, G. R. Lumpkin, M. G. Blackford, M. Colella and N. Zaluzec, J. In Situ Radiation Damage Studies of $\mathrm{La}_{\mathrm{x}} \mathrm{Sr}_{1-3 \mathrm{x} /}$ ${ }_{2} \mathrm{TiO}_{3}$ Perovskites, J. Appl. Phys., 2008, 103(8), 083531, DOI: 10.1063/1.2901183.

63 K. R. Whittle, M. de los Reyes, R. D. Aughterson, M. G. Blackford, K. L. Smith, P. Baldo, E. P. Ryan, N. J. Zaluzec and G. R. Lumpkin, In-Situ Irradiation of Ca(1-x)La(2/3x)TiO3 Defect Perovskites: The Role of Vacancies in Recovery, Materialia, 2018, 3, 186-191, DOI: 10.1016/j.mtla.2018.08.016.

64 S. M. Lawson, N. C. Hyatt, K. R. Whittle and A. S. Gandy, Resistance to Amorphisation in $\mathrm{Ca}_{1-\mathrm{x}} \mathrm{La}_{2 \mathrm{x} / 3} \mathrm{TiO}_{3}$ Perovskites - a Bulk Ion-Irradiation Study, Acta Mater., 2019, 180, 180-188, DOI: 10.1016/j.actamat.2019.09.006.

65 G. Greaves, A. H. Mir, R. W. Harrison, M. A. Tunes, S. E. Donnelly and J. A. Hinks, New Microscope and Ion Accelerators for Materials Investigations (MIAMI-2) System at the University of Huddersfield, Nucl. Instrum. Methods Phys. Res., Sect. A, 2019, 931, 37-43, DOI: 10.1016/j.nima.2019.03.074.

66 J. F. Ziegler, M. D. Ziegler and J. P. Biersack, SRIM - The Stopping and Range of Ions in Matter, Nucl. Instrum. Methods Phys. Res., Sect. B, 2010, 268(11-12), 1818-1823, DOI: 10.1016/j.nimb.2010.02.091.

67 G. R. Lumpkin, M. G. Blackford, K. L. Smith, K. R. Whittle, N. J. Zaluzec, E. a. Ryan and P. Baldo, Ion Irradiation of the $\mathrm{TiO}_{2}$ Polymorphs and Cassiterite, Am. Mineral., 2009, 95(1), 192-195, DOI: 10.2138/am.2010.3329.

68 J. Lian, J. Chen, L. Wang, R. Ewing, J. Farmer, L. Boatner and K. Helean, Radiation-Induced Amorphization of RareEarth Titanate Pyrochlores, Phys. Rev. B: Condens. Matter Mater. Phys., 2003, 68(13), 134107, DOI: 10.1103/ PhysRevB.68.134107.

69 J. Lian, L. Wang, G. R. Lumpkin and R. C. Ewing, Heavy Ion Irradiation of Brannerite-Type Ceramics, Mater. Res. Soc. Symp., 2001, 650, R3.17.1-R3.17.6, DOI: 10.1557/proc-650r3.17.

70 J. Lian, J. M. Zhang, V. Pointeau, F. X. Zhang, M. Lang, F. Y. Lu, C. Poinssot and R. C. Ewing, Response of Synthetic Coffinite to Energetic Ion Beam Irradiation, $J$. Nucl. Mater., 2009, 393(3), 481-486, DOI: 10.1016/ j.jnucmat.2009.07.005.

71 J. Zhang, F. Zhang, M. Lang, F. Lu, J. Lian and R. C. Ewing, Ion-Irradiation-Induced Structural Transitions in Orthorhombic $\mathrm{Ln}_{2} \mathrm{TiO}_{5}$, Acta Mater., 2013, 61(11), 41914199, DOI: 10.1016/j.actamat.2013.03.045. 
72 J. Wen, C. Sun, P. P. Dholabhai, Y. Xia, M. Tang, D. Chen, D. Y. Yang, Y. H. Li, B. P. Uberuaga and Y. Q. Wang, Temperature Dependence of the Radiation Tolerance of Nanocrystalline Pyrochlores $\mathrm{A}_{2} \mathrm{Ti}_{2} \mathrm{O}_{7}(\mathrm{~A}=\mathrm{Gd}$, Ho and $\mathrm{Lu})$, Acta Mater., 2016, 110, 175-184, DOI: 10.1016/ j.actamat.2016.03.025.

73 J. Zhou, T. Yao, J. Lian, Y. Shen, Z. Dong and F. Lu, Radiation-Induced Amorphization of Ce-Doped $\mathrm{Mg}_{2} \mathrm{Y}_{8}\left(\mathrm{SiO}_{4}\right)_{6} \mathrm{O}_{2}$ Silicate Apatite, Nucl. Instrum. Methods Phys. Res., Sect. B, 2016, 379, 102-106, DOI: 10.1016/ j.nimb.2016.04.008.

74 J. Zhou, T. Yao, D. Cao, J. Lian and F. Lu, In-Situ TEM Study of Radiation-Induced Amorphization and Recrystallization of Hydroxyapatite, J. Nucl. Mater., 2018, 512, 307-313, DOI: 10.1016/j.jnucmat.2018.10.018.

75 T. Yao, F. Lu, H. Zhang, B. Gong, W. Ji, L. Zuo and J. Lian, Radiation-Induced Amorphization of Langasite $\mathrm{La}_{3} \mathrm{Ga}_{5} \mathrm{SiO}_{14}$, J. Nucl. Mater., 2018, 500, 50-55, DOI: 10.1016/j.jnucmat.2017.12.023.

76 R. D. Aughterson, G. R. Lumpkin, M. de los Reyes, B. Gault, P. Baldo, E. Ryan, K. R. Whittle, K. L. Smith and J. M. Cairney, The Influence of Crystal Structure on IonIrradiation Tolerance in the $\mathrm{Sm}(\mathrm{x}) \mathrm{Yb}(2-\mathrm{x}) \mathrm{TiO} 5$ Series, $J$. Nucl. Mater., 2016, 471, 17-24, DOI: 10.1016/ j.jnucmat.2015.12.036.

77 W. Weber, Models and Mechanisms of Irradiation-Induced Amorphization in Ceramics, Nucl. Instrum. Methods Phys. Res., Sect. B, 2000, 166-167, 98-106, DOI: 10.1016/S0168583X(99)00643-6.

78 W. J. Weber, R. C. Ewing and L.-M. Wang, The RadiationInduced Crystalline-to-Amorphous Transition in Zircon, $J$. Mater. Res., 2011, 9(03), 688-698, DOI: $10.1557 /$ JMR.1994.0688.

79 M. Ganguly, S. K. Rout, W. S. Woo, C. W. Ahn and I. W. Kim, Characterization of A-Site Deficient Samarium Doped Barium Titanate, Phys. B, 2013, 411, 26-34, DOI: 10.1016/ j.physb.2012.11.006.

80 T. A. Whittle, W. R. Brant, J. R. Hester, Q. Gu and S. Schmid, Tailoring Phase Transition Temperatures in Perovskites: Via A -Site Vacancy Generation, Dalton Trans., 2017, 46(22), 7253-7260, DOI: 10.1039/c7dt00352h.

81 A. Bisen, A. Satapathy, S. Parida, E. Sinha, S. K. Rout and M. Kar, Structural, Optical Band Gap, Microwave Dielectric Properties and Dielectric Resonant Antenna Studies of $\mathrm{Ba}(1-\mathrm{x}) \mathrm{La}(2 \mathrm{x} / 3) \mathrm{ZrO} 3(0 \leq \mathrm{x} \leq 0.1)$ Ceramics, $J$. Alloys Compd., 2014, 615, 1006-1012, DOI: 10.1016/ j.jallcom.2014.07.007.

82 G. R. Lumpkin, M. Pruneda, S. Rios, K. L. Smith, K. Trachenko, K. R. Whittle and N. J. Zaluzec, Nature of the Chemical Bond and Prediction of Radiation Tolerance in Pyrochlore and Defect Fluorite Compounds, J. Solid State Chem., 2007, 180(4), 1512-1518, DOI: 10.1016/ j.jssc.2007.01.028.

83 M. Lang, F. X. Zhang, R. C. Ewing, J. Lian, C. Trautmann and Z. Wang, Structural Modifications of $\mathrm{Gd}_{2} \mathrm{Zr}_{2-\mathrm{x}} \mathrm{Ti}{ }_{\mathrm{x}} \mathrm{O}_{7}$ Pyrochlore Induced by Swift Heavy Ions: Disordering and
Amorphization, J. Mater. Res., 2009, 24(04), 1322-1334, DOI: 10.1557/jmr.2009.0151.

84 J. Lian, X. Zu, K. Kutty, J. Chen, L. Wang and R. Ewing, IonIrradiation-Induced Amorphization of $\mathrm{La}_{2} \mathrm{Zr}_{2} \mathrm{O}_{7}$ Pyrochlore, Phys. Rev. B: Condens. Matter Mater. Phys., 2002, 66(5), 054108, DOI: 10.1103/PhysRevB.66.054108.

85 G. R. Lumpkin, K. L. Smith, M. G. Blackford, K. R. Whittle, E. J. Harvey, S. a. T. Redfern and N. J. Zaluzec, Ion Irradiation of Ternary Pyrochlore Oxides, Chem. Mater., 2009, 21(13), 2746-2754, DOI: 10.1021/cm9003917.

86 J. Lian, R. C. Ewing, L. M. Wang and K. B. Helean, Ion-Beam Irradiation of Gd2Sn2O7 and Gd2Hf2O7 Pyrochlore: BondType Effect, J. Mater. Res., 2004, 19(05), 1575-1580, DOI: 10.1557/JMR.2004.0178.

87 S. K. Meena, A. Dashora, N. L. Heda and B. L. Ahuja, Compton Spectroscopy and Electronic Structure Study for Tetragonal Barium Titanate, Radiat. Phys. Chem., 2019, 158, 46-52, DOI: 10.1016/j.radphyschem.2019.01.007.

88 K. L. Smith, M. Colella, R. Cooper and E. R. Vance, Measured Displacement Energies of Oxygen Ions in Titanates and Zirconates, J. Nucl. Mater., 2003, 321(1), 1928, DOI: 10.1016/S0022-3115(03)00197-1.

89 R. Moos and K. H. Hardtl, Defect Chemistry of DonorDoped and Undoped Strontium Titanate Ceramics between $1000^{\circ}$ and $1400^{\circ} \mathrm{C}$, J. Am. Ceram. Soc., 2005, 80(10), 2549-2562, DOI: $\quad 10.1111 / \mathrm{j} .1151-$ 2916.1997.tb03157.x.

90 A. Chartier, C. Meis, J. P. Crocombette, L. R. Corrales and W. J. Weber, Atomistic Modeling of Displacement Cascades in $\mathrm{La}_{2} \mathrm{Zr}_{2} \mathrm{O}_{7}$ Pyrochlore, Phys. Rev. B: Condens. Matter Mater. Phys., 2003, 67(17), 1-13, DOI: 10.1103/ PhysRevB.67.174102.

91 B. S. Thomas, N. a. Marks and B. D. Begg, Defects and Threshold Displacement Energies in SrTiO3 Perovskite Using Atomistic Computer Simulations, Nucl. Instrum. Methods Phys. Res., Sect. B, 2007, 254(2), 211-218, DOI: 10.1016/j.nimb.2006.11.069.

92 K. L. Smith and N. J. Zaluzec, The Displacement Energies of Cations in Perovskite $\left(\mathrm{CaTiO}_{3}\right)$, J. Nucl. Mater., 2005, 336(23), 261-266, DOI: 10.1016/j.jnucmat.2004.09.021.

93 A. C. Iyasara, W. L. Schmidt, R. Boston, D. C. Sinclair and I. M. Reaney, $\mathrm{La}$ and $\mathrm{Sm}$ Co-Doped $\mathrm{SrTiO}_{3-}$ $\delta$ Thermoelectric Ceramics, Mater. Today: Proc., 2017, 4(12), 12360-12367, DOI: 10.1016/j.matpr.2017.10.004.

94 C. L. Freeman, J. A. Dawson, H. R. Chen, L. Ben, J. H. Harding, F. D. Morrison, D. C. Sinclair and A. R. West, Energetics of Donor-Doping, Metal Vacancies, and Oxygen-Loss in A-Site Rare-Earth-Doped $\mathrm{BaTiO}_{3}, \mathrm{Adv}$. Funct. Mater., 2013, 23(31), 3925-3928, DOI: 10.1002/ adfm. 201203147.

95 J. A. Dawson, X. Li, C. L. Freeman, J. H. Harding and D. C. Sinclair, The Application of a New Potential Model to the Rare-Earth Doping of $\mathrm{SrTiO}_{3}$ and $\mathrm{CaTiO}_{3}$, J. Mater. Chem. C, 2013, 1(8), 1574-1582, DOI: 10.1039/c2tc00475e.

96 Z. Lu, H. Zhang, W. Lei, D. C. Sinclair and I. M. Reaney, High-Figure-of-Merit Thermoelectric La-Doped A-Site- 
Deficient $\mathrm{SrTiO}_{3}$ Ceramics, Chem. Mater., 2016, 28(3), 925935, DOI: 10.1021/acs.chemmater.5b04616.

97 I. Akin, M. Li, Z. Lu and D. C. Sinclair, Oxygen-Loss in A-Site Deficient $\mathrm{Sr}_{0.85} \mathrm{La}_{0.1} \mathrm{TiO}_{3}$ Perovskite, RSC Adv., 2014, 1-6, DOI: $10.1039 / \mathrm{c} 4 \mathrm{ra04199b.}$

98 C. A. Taylor, M. K. Patel, J. A. Aguiar, Y. Zhang, M. L. Crespillo, J. Wen, H. Xue, Y. Wang and W. J. Weber, Combined Effects of Radiation Damage and $\mathrm{He}$ Accumulation on Bubble Nucleation in $\mathrm{Gd}_{2} \mathrm{Ti}_{2} \mathrm{O}_{7}, \mathrm{~J}$. Nucl. Mater., 2016, 479, 542-547, DOI: 10.1016/ j.jnucmat.2016.07.043.

99 C. A. Taylor, M. K. Patel, J. A. Aguiar, Y. Zhang, M. L. Crespillo, J. Wen, H. Xue, Y. Wang and W. J. Weber, Bubble Formation and Lattice Parameter Changes Resulting from He Irradiation of Defect-Fluorite $\mathrm{Gd}_{2} \mathrm{Zr}_{2} \mathrm{O}_{7}$, Acta Mater., 2016, 115, 115-122, DOI: $10.1016 /$ j.actamat.2016.05.045.
100 N. Sasajima, T. Matsui, S. Furuno, K. Hojou and H. Otsu, Damage Accumulation in $\mathrm{Al}_{2} \mathrm{O}_{3}$ during $\mathrm{H}^{2+}$ or $\mathrm{He}^{+}$Ion Irradiation, Nucl. Instrum. Methods Phys. Res., Sect. B, 1999, 148(1-4), 745-751, DOI: 10.1016/S0168-583X(98) 00810-6.

101 M. A. van Huis, A. van Veen, F. Labohm, A. V. Fedorov, H. Schut, B. J. Kooi and J. T. M. De Hosson, Formation, Growth and Dissociation of He Bubbles in $\mathrm{Al}_{2} \mathrm{O}_{3}, \mathrm{Nucl}$. Instrum. Methods Phys. Res., Sect. B, 2004, 216, 149-155, DOI: 10.1016/j.nimb.2003.11.071.

102 N. C. Hyatt, C. L. Corkhill, M. C. Stennett, R. J. Hand, L. J. Gardner and C. L. Thorpe, The HADES Facility for High Activity Decommissioning Engineering \& Science: Part of the UK National Nuclear User Facility, IOP Conf. Ser.: Mater. Sci. Eng., 2020, 818, 012022, DOI: 10.1088/ 1757-899x/818/1/012022. 